Zhang, G. and Lai, C. and Hartmann, P. and Oddy, W. and Kusel, M. and Sly, P. and Holt, P. 2014. Anti-Infective Proteins in Breast Milk and Asthma-Associated Phenotypes During Early Childhood. Pediatric Allergy and Immunology. 25 (6): pp. 544-551.

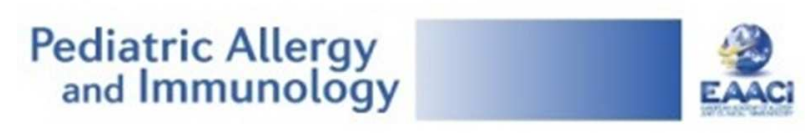

\title{
Anti-infective proteins in breast milk and asthma-associated phenotypes during early childhood
}

\begin{tabular}{|r|l|}
\hline Journal: & Pediatric Allergy and Immunology \\
\hline Manuscript ID: & PAI-14-O-0162.R2 \\
\hline Manuscript Type: & Original \\
\hline Complete List of Authors: & $\begin{array}{r}\text { Zhang, Guicheng; Curtin University, School of Public Health } \\
\text { Lai, Ching-tat; The University of Western Australia, School of Chemistry } \\
\text { and Biochemistry, Faculty of Science } \\
\text { Hartmann, Peter; The University of Western Australia, School of Chemistry } \\
\text { and Biochemistry, Faculty of Science } \\
\text { Oddy, Wendy; Telethon Kids Institute, Population Sciences; The University } \\
\text { of Western Australia, } \\
\text { Kusel, Merci; Telethon Kids Institute, Clinical Sciences; The University of } \\
\text { Western Australia, } \\
\text { Sly, Peter; The University of Queensland, Queensland Children's Medical } \\
\text { Research Institute } \\
\text { Holt, Patrick; Telethon Kids Institute, Cell Biology; The University of } \\
\text { Western Australia, }\end{array}$ \\
\hline Topics of paper: & $\begin{array}{l}\text { nutrition: breast milk, asthma: infectious diseases, asthma: } \\
\text { pathophysiology, epidemiology: Epidemiology of asthma, epidemiology: } \\
\text { Epidemiology of allergies }\end{array}$ \\
\hline & \\
\hline
\end{tabular}

\section{SCHOLARONE ${ }^{\text {M }}$}

Manuscripts 
Zhang, G. and Lai, C. and Hartmann, P. and Oddy, W. and Kusel, M. and Sly, P. and Holt, P. 2014. Anti-Infective Proteins in Breast Milk and Asthma-Associated Phenotypes During Early Childhood. Pediatric Allergy and Immunology. 25 (6): pp. 544-551.

\section{1 \\ Anti-infective proteins in breast milk and asthma-associated phenotypes during early childhood}

Zhang, Guicheng*1; Lai, Ching Tat*²; Hartmann, Peter ${ }^{2}$; Oddy, Wendy $\mathrm{H}^{3}$; Kusel, Merci MH ${ }^{3}$; Sly, Peter D ${ }^{4}$; Holt Patrick G ${ }^{3,4}$

* contribute equally

${ }^{1}$ School of Public Health, Curtin University, Perth, Western Australia, Australia

2 School of Chemistry and Biochemistry, Faculty of Science, The University of Western Australia, Perth, Western Australia, Australia

${ }^{3}$ Telethon Kids Institute, The University of Western Australia, Perth, Western Australia, Australia

${ }^{4}$ University of Queensland, Queensland Children's Medical Research Institute, Brisbane, Queensland, Australia

Running title: Breast milk proteins and risk for atopy/asthma

Corresponding Authors:

Prof Patrick G Holt

Professor P G Holt

Division of Cell Biology

Telethon Kids Institute

PO Box 855

West Perth WA 6872 Australia

Tel: $\quad+61894897838$

Email: Patrick.Holt@telethonkids.org.au

Marina.Stubbs@telethonkids.org.au

Dr Guicheng Zhang, School of Public Health, Curtin University

Email: brad.zhang@,curtin.edu.au

Word Count; 3022 


\section{$38 \quad$ Abstract}

\section{Background}

The impact of breastmilk feeding on susceptibility to asthma in childhood is highly controversial, due in part to failure of the majority of studies in the area to adequately account for key confounders exemplified by respiratory infection history, plus the effects of recall bias.

\section{Methods}

As part of a prospective cohort study on the role of respiratory infections in asthma development in high-risk children, we measured the concentration of a panel of anti-infective proteins in maternal milk samples, and analysed associations between these and subsequent atopy-, infection- and asthma-related outcomes prospectively to age 10 years.

\section{Results}

We observed significant but transient inverse associations between the concentration of milk proteins and susceptibility to upper respiratory infections in year 1 only, and parallel but positive transient associations with early lower respiratory infections and atopy. No associations were seen with asthmarelated outcomes.

\section{Conclusions}

Breast milk feeding may influence the expression of inflammatory symptoms associated with respiratory infections and atopy in early life but these effects appear to be inconsistent and transient. The heterogeneous nature of breastfeeding effects suggests it may influence systemic immunoinflammatory function at several different levels. 
Zhang, G. and Lai, C. and Hartmann, P. and Oddy, W. and Kusel, M. and Sly, P. and Holt, P. 2014. Anti-Infective Proteins in Breast Milk and Asthma-Associated Phenotypes During Early Childhood. Pediatric Allergy and Immunology. 25 (6): pp. 544-551.

62

63

64 Keywords: atopy, breast feeding, infancy, respiratory infection, wheezing, IgA, lysozyme, lactoferrin

65

66

67 


\section{Introduction}

Breastfeeding is widely acknowledged to have protective effects against a range of health problems in infancy and childhood, as well as reducing risk for some chronic diseases that manifest in later life ${ }^{1}$. Until comparatively recently, allergy-associated syndromes including atopic asthma were paramount amongst the list of diseases reportedly susceptible to the protective effects of breastfeeding, ${ }^{2,3}$ and recommendations for exclusive breastfeeding for the first 6 months of life have been a prominent feature of many official guidelines aimed at allergy prevention ${ }^{4,5}$.

However, a growing body of information derived from birth cohort studies has questioned the validity of this paradigm. The relevant findings include observations linking early introduction of allergenic foods with decreased risk of subsequent food allergy ${ }^{6,7}$, the lack of evidence from the large scale ISAAC study for any protective effect of exclusive breastfeeding against eczema ${ }^{8}$, and suggestive evidence that in certain populations breastfeeding may even increase long term risk for atopy and asthma $^{9,10}$.

The relationship between breastfeeding and asthma/allergic disease risk remains highly controversial. Complicating this debate is the growing realization that the majority of the available studies which have shaped current opinions in this area suffer from methodological flaws that mitigate against reaching firm conclusions ${ }^{9,11}$. The protective effects of breastfeeding on infection and allergic conditions are known to be largely derived from the proteins of human milk ${ }^{12}$. Amongst the most important are secretory immunoglobulin A (sIgA), lysozyme and lactoferrin which are major whey proteins which are well known for their immune properties against a range of infections and diseases ${ }^{12}$. 
Zhang, G. and Lai, C. and Hartmann, P. and Oddy, W. and Kusel, M. and Sly, P. and Holt, P. 2014. Anti-Infective Proteins in Breast Milk and Asthma-Associated Phenotypes During Early Childhood. Pediatric Allergy and Immunology. 25 (6): pp. 544-551.

91 Together with other immune proteins in human milk, they assist infants to establish and strengthen

92 their immunity against infections and diseases later in life ${ }^{13}$.

93 Our aim in the present study was to ascertain whether these protein components of breast milk have

94 demonstrable activity in relation to protection of children against asthma and allergy. The findings

95 reported below are derived from a subgroup of subjects from the Perth CAS cohort ${ }^{14-17}$, the design of

96 which enables examination of this issue from a unique perspective. Notably, this study had a primary

97 focus on respiratory infection and as such included physician verification and clinical assessment of all parent-reported putative infection events within the first 5 years of life. Moreover, the subgroup from this cohort utilized for these analyses was restricted to children whose mothers provided breast milk samples, and the study mothers were closely monitored and supported by the clinical team including collection and analysis of breast milk samples at 6 weeks and 6 months post partum. In addition to physician-monitoring of each respiratory infection event in these children, objective assessment of allergy-associated and asthma-associated clinical phenotypes was performed at $6 \mathrm{mths}$ and annually to age 5 years, with additional followup at age 10 years. This approach enabled collection of a unique data set for examination of the question of whether breast feeding influences allergy/asthma susceptibility from a perspective not previously considered in detail i.e. whether differences in the concentration of key protein constituents in milk (milk "quality") were associated with variations in disease risk amongst recipients. The milk constituents chosen for these analyses were secretory immunoglobulin A (sIgA), lysozyme and lactoferrin, in addition to total protein. 
111

112

113

114

115

116

117

118

119

120

121

122

123

124

125

126

127

128

129

130

131

132

133

134

\section{Methodology}

\section{Subjects}

142 mother:infants pairs from the CAS cohort ${ }^{16,17}$ were included in the milk study. The cohort was initiated in 1996 in the Perth metropolitan area, all subjects were enrolled antenatally and classified as having an atopic family history based on a standard questionnaire and a positive doctor's diagnosis of asthma, hay fever, or atopic dermatitis for 1 or both parents. The cohort has been follow up at 6 weeks, 6 months, 1, 2, 3, 4, 5 and 10 years with comprehensive assessment of allergic and asthmatic phenotypes $^{15-17}$.

Breastfeeding history was monitored through dietary questionnaire administered at the 6 week and 6 month visits and breast milk samples were collected at these visits. Infectious episodes were prospectively recorded throughout the first 5 years with a daily parental diary; parents were trained to summon the clinical team at every incidence of suspected respiratory infection, enabling symptom verification during the ensuing home visits by the clinical team. Acute respiratory infections (ARIs) were subclassified as lower respiratory infection (LRI), wheezy lower respiratory infection (wLRI) and upper respiratory infection (URI) as detailed in the online supplement. Skin prick tests to a panel of ingested and aero- allergens were performed at 6 months, 2 years, 5 and 10 years to define atopy. The subjects were examined for eczema on each of the scheduled followup visits as well as during all home visits for respiratory episodes during the first 5 years. Eczema was defined as doctor diagnosis of eczema or atopic dermatitis experienced by child in last 12 months. Wheezing is the parental opinion of whether child wheezed in last 12 months. Asthma was defined as wheeze during last 12 months (parent opinion) plus Doctor diagnosis of asthma beyond the second birthday. 
Zhang, G. and Lai, C. and Hartmann, P. and Oddy, W. and Kusel, M. and Sly, P. and Holt, P. 2014. Anti-Infective Proteins in Breast Milk and Asthma-Associated Phenotypes During Early Childhood. Pediatric Allergy and Immunology. 25 (6): pp. 544-551.

135 The milk samples were stored at $-20^{\circ} \mathrm{C}$ after collection. Before biochemical analysis, thawed milk 136 samples were centrifuged at 10000 RPM for 10 minutes. The tube was sliced to remove the fat layer.

137 The sIgA, lysozyme, lactoferrin and total protein were assayed in the defatted milk.

Lysozyme in the samples was measured by a modification of Selsted \& Martinez ${ }^{18}$. Lactoferrin and sIgA in the samples was determined by ELISA ${ }^{19}$. Total protein was determined by a protein assay that measured the binding of the protein dye (Bio-Rad) to the primarily basic and aromatic amino acid residues of the proteins. Further assay details appear in the online supplement

\section{Statistical analysis}

144 Protein levels were log-transformed to have an approximately normal distribution. As the number of infectious episodes such as URI and LRI was a count variable Poison regression was employed to investigate the associations between levels of milk proteins and the incidence of respiratory infections. In order to examine the associations of breast milk proteins with binary outcomes such as atopy, eczema, wheezing and asthma we compared the levels of these between the two scenarios of these binary outcomes using general linear models after adjusting for gender, passive smoking and number of older siblings. All the analyses were conducted using IBM SPSS Statistics 20.

\section{Results}

In this subcohort there were initially 142 infants. Five infants who were partly fed with formula were subsequently excluded from the analyses. Table 1 shows the characteristics of 137 children included in the present study and the remaining children in the longitudinal cohorts. The children for this study appeared to have lower prevalence of smoking exposure and childcare attendance at age 1, compared with the remaining children. Table 2 shows prevalence of these conditions in the 137 children who completed the study. 


\section{Levels of breast milk proteins}

161 Within individual milk donors, the concentrations of sIgA, lactoferrin, lysozyme and total protein

varied between breasts at both six weeks and six months of lactation (Table 3). The range in the

concentrations of sIgA, lactoferrin, lysozyme and total protein from each breast at both six weeks and

six months of lactation was large (Table 3). At six weeks of lactation, the mean concentrations of the

right and left breasts for sIgA were $(0.67 \pm 0.36 \mathrm{~g} / \mathrm{l})$, lactoferrin was $(2.59 \pm 1.58)$, lysozyme was $(0.07 \pm$

$0.07 \mathrm{~g} / \mathrm{l})$ and total protein was $(15.1 \pm 12.87 \mathrm{~g} / \mathrm{l})$ respectively. At six months of lactation, the mean

concentrations of the right and left breasts for sIgA were $(0.71 \pm 0.40 \mathrm{~g} / 1)$, lactoferrin was $(2.13 \pm 1.29)$,

lysozyme was $(0.11 \pm 0.11 \mathrm{~g} / \mathrm{l})$ and total protein was $(12.1 \pm 5.84 \mathrm{~g} / \mathrm{l})$ respectively. There were

significant changes in the concentration of sIgA, lactoferrin, lysozyme and total protein in milk from

both breasts, except sIgA (left breast only), between six weeks and six months of lactation (data not

shown). All subsequent analyses utilized mean data from two breasts for each mother in the study.

Atopy

174

We investigated associations between the concentrations of breast milk proteins with atopy defined by

skin prick tests (SPT) at age 6 months, 2 and 5 years. We chose to measure atopy status at multiple

time points in light of our early demonstration ${ }^{14}$ that $\operatorname{IgE}$ production is commonly cyclical over time

during the preschool years. The levels of milk proteins in the study population are shown in Figure 1,

stratified by atopy outcomes in their offspring at these three time points. sIgA concentrations in milk

$182=0.028)$ and 6 month $(\mathrm{p}=0.009)$ total protein levels $($ Fig 1d). Similar effects were observed with 
Zhang, G. and Lai, C. and Hartmann, P. and Oddy, W. and Kusel, M. and Sly, P. and Holt, P. 2014. Anti-Infective Proteins in Breast Milk and Asthma-Associated Phenotypes During Early Childhood. Pediatric Allergy and Immunology. 25 (6): pp. 544-551.

183

184

185

186

187

188

189

190

191

192

193

194

195

196

197

198

199

200

201

202

203

204

205

respect to total protein levels in maternal milk samples (Fig 1d), which were significantly higher at both 6 weeks $(p=0.001)$ and 6 months $(p=0.012)$ in mothers whose infants developed atopy by age 2 . It appeared that this relationship persisted up to outcome age 2 years but was lost by 5 years; additional regression modeling of 10 year data also did not demonstrate significant associations between milk protein content and atopy outcomes.

\section{Eczema}

Eczema was assessed at each followup of the cohort. We compared levels of individual breast milk proteins in offspring with and without eczema at these time points after adjusting for gender, number of older children and passive smoking, and results out to year 3 are shown in Table 4 (as above, unadjusted data yielded similar results). Positive associations were observed between Lactoferrin levels and eczema outcomes at 6 months and 1 and 3 years, but not beyond these time points (not shown) with an exception that a marginal effect of milk lysozyme at 6 months on current eczema at age 10 was also observed. $(\mathrm{p}=0.048)$.

\section{Respiratory infections}

We assessed associations between levels of maternal milk proteins and risk in their offspring for respiratory infections in the first 3 years, using Poisson regression models and adjusting for gender, passive smoking and number of older siblings. Generally, the presence of high levels of anti-infective proteins were associated with reduced frequency of URIs $(\operatorname{IRR}<1)$ in the first two years of life (Supplementary Table 1). sIgA levels were associated with a decreased risk for URIs in the first year of life at a significance of $\mathrm{p}=0.035$ and 0.079 for milk samples collected at 6 weeks and 6 months, respectively, and similarly for Lactoferrin levels in 6 month samples $(p=0.008)$. With respect to year 2 
Zhang, G. and Lai, C. and Hartmann, P. and Oddy, W. and Kusel, M. and Sly, P. and Holt, P. 2014. Anti-Infective Proteins in Breast Milk and Asthma-Associated Phenotypes During Early Childhood. Pediatric Allergy and Immunology. 25 (6): pp. 544-551.

URI outcomes, 6 week IgA and 6 month Lactoferrin levels were also significantly associated with a decreased risk for URI ( $\mathrm{p}=0.005$ and 0.015 respectively). These associations diminished beyond year 2 .

No associations were observed that were consistent with parallel milk-mediated protection against the spread and/or intensification of infections in the lower respiratory tract. Instead, high levels of Lactoferrin and/or Lysozyme in early milk samples were paradoxically associated with increased risk for wheezing lower respiratory infections, but only during the first year of life (Supplementary Table 2).

\section{Wheezing and asthma}

Current wheezing was evaluated at each annual visit and asthma was defined at ages 3, 4, 5 and 10 years. No significant associations were found between the concentrations of breast milk proteins with these phenotypes employing either adjusted or raw data utilized above (not shown). In followup analyses we also tested multiple regression models in which qualitative and quantitative respiratory tract infection history over the first two years of life were included as additional confounders, and again could not identify any significant linkages between milk protein levels and asthma-associated phenotypes (data not shown).

\section{Discussion}

The focus of studies in the CAS birth cohort is on identification of factors driving asthma pathogenesis during childhood. Our previous investigations in this cohort have identified early allergic sensitization and concomitant respiratory tract infections as major asthma risk factors ${ }^{16}$. These can operate independently to drive asthma development, however the highest level of risk is observed in children who experience both sensitization and respiratory tract infections concomitantly during this period ${ }^{14}$. 
Zhang, G. and Lai, C. and Hartmann, P. and Oddy, W. and Kusel, M. and Sly, P. and Holt, P. 2014. Anti-Infective Proteins in Breast Milk and Asthma-Associated Phenotypes During Early Childhood. Pediatric Allergy and Immunology. 25 (6): pp. 544-551.

230 The initial diagnosis of asthma in the cohort was made at age 5 years ${ }^{16}$, but more recently it was shown

231 that these effects carry through to at least 10 years ${ }^{15}$. It is additionally noteworthy that the relevant

232 infections are those that spread to the lower respiratory tract and attain sufficient severity to trigger

233 symptoms of wheeze and/or fever, whereas infections that remain restricted to the upper respiratory

234 tract are benign in this context ${ }^{15,16}$.

It is reasonable to consider breast milk intake as a potential factor that may modulate asthma risk in

CAS cohort subjects for a number of reasons, in particular (i) an earlier literature suggesting that breast

milk feeding can protect against allergic sensitization (e.g. ${ }^{3}$ ); (ii) the well established role of breastfeeding in protecting infants against both enteric and respiratory infections ${ }^{22}$; and (iii) the reports from earlier observational studies linking exclusive breast feeding with reduced rates of subsequent wheeze ${ }^{23-25}$.

These claims have biological plausibility at several levels. Notably, it has been established that innate and adaptive immune functions in all infants are in a functionally quiescent state at birth ${ }^{26-28}$, and mature postnatally in response to environmental microbial stimulation, especially from commensal organisms in the gastrointestinal tract (reviewed ${ }^{29,30}$ ) but also from common childhood infections (the "Hygiene Hypothesis"31). However, as noted above, certain categories of severe respiratory infections appear to have the opposite effects in relation to risk of asthma, likely due in part to direct inflammatory damage to developing lung function extrinsic to any influence on immune system maturation $^{32}$.

The kinetics of postnatal immune maturation is sluggish in a significant subset of children at high risk 
benign childhood infections, and/or patterns of colonization with commensal microflora, may influence this process in ways that cannot be predicted. In this regard it is noteworthy that a growing literature has implicated breast milk feeding as an important modulator of quantitative and qualitative aspects of postnatal bacterial colonization of the $\mathrm{GIT}^{35-37}$.

These complexities may explain some of the disparities in the literature on relationships between breast feeding and future atopy/asthma outcomes, and likewise some of the apparent contradictions in our findings above from the CAS cohort. Notably, a clear finding in these subjects was the inverse association between levels of the anti-infectives IgA and Lactoferrin in milk and risk for upper respiratory infections in year 1, which extended into year 2 (Table 4). However, these protective effects were not seen with respect to the lower respiratory tract, and instead levels of milk proteins (in this case Lactoferrin and Lysozyme) were positively associated with risk for wheezing infections (Table 5). Similar positive relationships were observed between levels of milk proteins and early atopic outcomes measured as either SPT reactivity (Figs 1 and 2) or eczema Table 3; Fig 3); in both cases these effects were transient and were not generally seen beyond 2 years. In this regard we have previously reported that increased amounts of omega-3 fatty acids in maternal milk at 6 weeks protected against eczema at 6 months, but this protection did not continue to later ages ${ }^{38}$.

The dichotomous nature of our findings cannot be fully explained, but some possibilities can be considered. Firstly, breast milk feeding-associated protection against relatively mild URI at/around the time of infancy is not unexpected and is consistent with what is known re the anti-infective properties of maternal milk mediated via direct effects of anti-microbial molecules on incoming pathogens. 
Zhang, G. and Lai, C. and Hartmann, P. and Oddy, W. and Kusel, M. and Sly, P. and Holt, P. 2014. Anti-Infective Proteins in Breast Milk and Asthma-Associated Phenotypes During Early Childhood. Pediatric Allergy and Immunology. 25 (6): pp. 544-551.

277 However the reasons for dissociation between these URI effects and those relating to susceptibility to atopy and/or the spread of infections to the LRI are unclear. Possible explanations include (i) these severe LRI events may reflect higher pathogen loads that are beyond the range that is potentially controllable by milk-born anti-infectives; (ii) resistance to infection spread/intensification and to atopic sensitization in infants may depend upon defence mechanisms that are discrete from those that protect against URI, in particular cellular immune mechanisms that are reliant upon "endogenous" maturationinducing microbial signals, particularly from GIT commensals, colonization with which is likely influenced by milk-born anti-infectives. However it is not feasible to directly test these possibilities with the available data.

The most clearcut finding in our study is the lack of discernible milk protein quality-associated effects on asthma-related outcomes that persist beyond early childhood. It is pertinent to reiterate that these outcomes have been shown to be highly sensitive to early history of both atopy and LRI in this cohort $^{14-16}$, which as noted above are transiently influenced by breast milk quality, but apparently not to a degree which influences subsequent susceptibility to asthma. Our findings are thus consistent with the growing body of evidence suggesting that the long-term benefits of breast milk feeding in relation to these atopy- and asthma-associated phenotypes are limited ${ }^{6-10}$ but we cannot completely exclude effects based on our study because our sample size is small. We have described all statistical analyses carried out and did not make multiple test corrections because (i) they can be overly conservative and may inflate type II errors and (ii) our analyses were based on an a priori hypothesis ${ }^{39}$.

In conclusion it is relevant to acknowledge the limitations of this study. Firstly regarding the lack of association between wheezing/asthma and levels of milk proteins we acknowledge the possible type II errors due to relatively small sample size, which also precluded further sub-group analysis on the 
Zhang, G. and Lai, C. and Hartmann, P. and Oddy, W. and Kusel, M. and Sly, P. and Holt, P. 2014. Anti-Infective Proteins in Breast Milk and Asthma-Associated Phenotypes During Early Childhood. Pediatric Allergy and Immunology. 25 (6): pp. 544-551.

301 effects of milk proteins on other outcomes. However, this is a longitudinal cohort with wheezing 302 phenotypes comprehensively investigated, which is superior to a cross-sectional study. There were strong correlations between levels of individual proteins and the total milk proteins. We, therefore, 304 could not further clarify the effects of individual proteins in this cohort. Additionally, while unlike 305 previous investigations we have been able to include comprehensive data relating to the potential 306 confounding effects of infection history in regression models of milk-related effects on asthma307 associated outcomes, this remains a relatively small study, and larger sample sizes with greater statistical power may be required to finally resolve this issue. Also, our study population are all at high genetic risk for atopy/asthma and thus representative of $40-45 \%$ of the pediatric population, and accordingly are not representative of the general population. 
Zhang, G. and Lai, C. and Hartmann, P. and Oddy, W. and Kusel, M. and Sly, P. and Holt, P. 2014. Anti-Infective Proteins in Breast Milk and Asthma-Associated Phenotypes During Early Childhood. Pediatric Allergy and Immunology. 25 (6): pp. 544-551.

\section{Figure legends:}

313 Figure 1 The adjusted geometric means (g/l) and 95\% confidence intervals of milk proteins collected at

3146 weeks $(6 \mathrm{w})$ and 6 months $(6 \mathrm{~m})$, stratified by atopy assessed using skin prick tests at 6 months, 2 and

3155 years of age; General linear models were employed for the analyses with gender, passive smoking

316 and number of older children adjusted for; a: sIgA, b: Lysozyme, c: Lactoferrin, and d: Total Protein;

317 - Solid square, children with atopy (yes) $\Delta$ : Open triangle, children without atopy (no)

318

319

320

321

322

323

324

325

326

327

328

329

330

331

332

333

334

335 
1. Dieterich CM, Felice JP, O'Sullivan E, Rasmussen KM. Breastfeeding and health outcomes for the mother-infant dyad. Pediatr Clin North Am 2013;60:31-48.

2. Oddy WH, de Klerk NH, Sly PD, Holt PG. The effects of respiratory infections, atopy, and breastfeeding on childhood asthma. European Respiratory Journal 2002;19:899-905.

3. Oddy WH, Holt PG, Sly PD, et al. Association between breast feeding and asthma in 6 year old children: findings of a prospective birth cohort study. BMJ (Clinical research ed) 1999;319:815-9.

4. NHMRC. Eat for Health: Australian Dietary Guidelines. In: Australia NHMRCo, ed.: National Health and Medical Research Council of Australia; 2013:36.

5. Kramer MS, Kakuma R. The optimal duration of exclusive breastfeeding: a systematic review. Adv Exp Med Biol 2004;554:63-77.

6. Du Toit G, Katz Y, Sasieni P, et al. Early consumption of peanuts in infancy is associated with a low prevalence of peanut allergy. J Allergy Clin Immunol 2008;122:984-91.

350

7. Koplin JJ, Osborne NJ, Wake M, et al. Can early introduction of egg prevent egg allergy in infants? A population-based study. J Allergy Clin Immunol 2010;126:807-13.

8. Flohr C, Nagel G, Weinmayr G, et al. Lack of evidence for a protective effect of prolonged breastfeeding on childhood eczema: lessons from the International Study of Asthma and Allergies in Childhood (ISAAC) Phase Two. Br J Dermatol 2011;165:1280-9.

355 9. Sears MR, Greene JM, Willan AR, et al. Long-term relation between breastfeeding and 356 development of atopy and asthma in children and young adults: a longitudinal study. Lancet 2002;360:901-7. feeding to asthma and recurrent wheeze in childhood. Thorax 2001;56:192-7. 
Zhang, G. and Lai, C. and Hartmann, P. and Oddy, W. and Kusel, M. and Sly, P. and Holt, P. 2014. Anti-Infective Proteins in Breast Milk and Asthma-Associated Phenotypes During Early Childhood. Pediatric Allergy and Immunology. 25 (6): pp. 544-551.

360

361

362

11. Matheson MC, Allen KJ, Tang ML. Understanding the evidence for and against the role of breastfeeding in allergy prevention. Clin Exp Allergy 2012;42:827-51.

12. Lonnerdal B. Bioactive proteins in human milk: mechanisms of action. The Journal of pediatrics 2010;156:S26-30.

13. Walker A. Breast milk as the gold standard for protective nutrients. The Journal of pediatrics 2010;156:S3-7.

14. Holt P, Rowe J, Kusel M, et al. Towards improved prediction of risk for atopy and asthma amongst preschoolers: a prospective cohort study. J Allergy Clin Immunol 2010;125:645-51.

15. Kusel M, Kebadze T, Johnston S, Holt P, Sly P. Febrile respiratory illnesses in infancy and atopy are risk factors for persistent asthma and wheeze. European Respiratory Journal 2012;39:876-82.

16. Kusel MM, de Klerk NH, Kebadze T, et al. Early-life respiratory viral infections, atopic sensitization, and risk of subsequent development of persistent asthma. Journal of Allergy and Clinical Immunology 2007;119:1105-10.

17. Kusel MMH, de Klerk NH, Holt PG, Kebadze T, Johnston SL, Sly PD. Role of respiratory viruses in acute upper and lower respiratory tract illness in the first year of life - A birth cohort study. Pediatric Infectious Disease Journal 2006;25:680-6.

18. Selsted ME, Martinez RJ. A simple and ultrasensitive enzymatic assay for the quantitative determination of lysozyme in the picogram range. Anal Biochem 1980;109:67-70.

19. Tijssen P. Laboratory techniques in biochemistry and molecular biology. In: Burdon RHavK, P.H., ed. Practice and theory of immunoessays. New York: Elsevier; 1985.

20. Atwood CS, Hartmann PE. Collection of fore and hind milk from the sow and the changes in milk composition during suckling. J Dairy Res 1992;59:287-98.

21. Hambraeus L, Lonnerdal B, Forsum E, Gebre-Medhin M. Nitrogen and protein components of human milk. Acta Paediatr Scand 1978;67:561-5. 
384

385

386

387

388

389

390

391

392

393

394

395

396

397

398

399

400

401

402

403

404

405

406

407

22. Paramasivam K, Michie C, Opara E, Jewell AP. Human breast milk immunology: a review. Int

J Fertil Womens Med 2006;51:208-17.

23. Aberg N, Engstrom I, Lindberg U. Allergic diseases in Swedish school children. Acta Paediatr Scand 1989;78:246-52.

24. Chandra RK. Five-year follow-up of high-risk infants with family history of allergy who were exclusively breast-fed or fed partial whey hydrolysate, soy, and conventional cow's milk formulas. J Pediatr Gastroenterol Nutr 1997;24:380-8.

25. Kaufman HS, Frick OL. The development of allergy in infants of allergic parents: a prospective study concerning the role of heredity. Ann Allergy 1976;37:410-5.

26. Levy O. Innate immunity of the newborn: basic mechanisms and clinical correlates. Nat Rev Immunol 2007;7:379-90.

27. Siegrist CA. Vaccination in the neonatal period and early infancy. Int Rev Immunol 2000;19:195-219.

28. Holt PG. Postnatal maturation of immune competence during infancy and childhood [Review]. Pediatric Allergy and Immunology 1995;6:59-70.

29. Holt PG. Environmental factors and primary T-cell sensitization to inhalant allergens in infancy: reappraisal of the role of infections and air pollution [Review]. Pediatric Allergy and Immunology 1995;6:1-10.

30. Rook GA, Stanford JL. Give us this day our daily germs. Immunology Today 1998;19:113-6.

31. Strachan DP. Hay fever, hygiene, and household size. Br Med J 1989;299:1259-60.

32. Holt PG, Sly PD. Viral Infections and atopy in asthma pathogenesis: new rationales for asthma prevention and treatment. Nature Medicine 2012;18:726-35.

33. Holt PG, Clough JB, Holt BJ, et al. Genetic 'risk' for atopy is associated with delayed postnatal maturation of T-cell competence. Clinical and Experimental Allergy 1992;22:1093-9. 
Zhang, G. and Lai, C. and Hartmann, P. and Oddy, W. and Kusel, M. and Sly, P. and Holt, P. 2014. Anti-Infective Proteins in Breast Milk and Asthma-Associated Phenotypes During Early Childhood. Pediatric Allergy and Immunology. 25 (6): pp. 544-551.

408 34. Prescott SL, Macaubas C, Smallacombe T, Holt BJ, Sly PD, Holt PG. Development of allergen409 specific T-cell memory in atopic and normal children. Lancet 1999;353:196-200.

410 35. Favier CF, de Vos WM, Akkermans AD. Development of bacterial and bifidobacterial 411 communities in feces of newborn babies. Anaerobe 2003;9:219-29.

412 36. Meyers CA, Hess KR, Yung WK, Levin VA. Cognitive function as a predictor of survival in 413 patients with recurrent malignant glioma. J Clin Oncol 2000;18:646-50.

414 37. Kleessen B, Bunke H, Tovar K, Noack J, Sawatzki G. Influence of two infant formulas and 415 human milk on the development of the faecal flora in newborn infants. Acta Paediatr Scand $416 \quad 1995 ; 84: 1347-56$.

417 38. Oddy WH, Pal S, Kusel MM, et al. Atopy, eczema and breast milk fatty acids in a high-risk 418 cohort of children followed from birth to 5 yr. Pediatr Allergy Immunol 2006;17:4-10.

419 39. Perneger TV. What's wrong with Bonferroni adjustments. BMJ (Clinical research ed) $420 \quad 1998 ; 316: 1236-8$. 
Zhang, G and Lai, C and Hartmann, P. and Oddy, W and Kusel, M and Sly, P and Holt, P. 2014. Anti-lnfective Proteins in Breast Milk and Asthma-Associated Phenotypes During Early Childhood. Pediatric Allergy and Immunology. 25 (6): pp. 544-551.

Table 1 The comparison of the 137 children and the remaining children in the longitudinal cohort

\begin{tabular}{|c|c|c|c|}
\hline & $\begin{array}{l}137 \text { children for milk protein analysis } \\
\qquad \mathrm{n} / \mathrm{N}(\%)\end{array}$ & $\begin{array}{l}\text { Remaining children } \\
\mathrm{n} / \mathrm{N}(\%)\end{array}$ & $\mathrm{p}$ \\
\hline Males & $83 / 137(60.6)$ & $63 / 124(50.8)$ & 0.11 \\
\hline Maternal atopy history & $106 / 135(78.5)$ & $71 / 89(79.8)$ & 0.82 \\
\hline Paternal atopy history & $92 / 135(68.1)$ & $59 / 89(66.3)$ & 0.77 \\
\hline Exposure to passive smoking at age 1 & $19 / 134(14.2)$ & $25 / 93(26.9)$ & 0.017 \\
\hline Exposure to passive smoking at age 5 & $13 / 122(10.7)$ & $17 / 76(22.4)$ & 0.025 \\
\hline Childcare attendance at age 1 & $32 / 134(23.9)$ & $34 / 93(36.6)$ & 0.039 \\
\hline Childcare attendance at age 5 & $52 / 129(40.3)$ & $45 / 91(49.5)$ & 0.18 \\
\hline Asthma at age 5 & $23 / 122(18.9)$ & $12 / 76(15.8)$ & 0.58 \\
\hline
\end{tabular}


Zhang, G. and Lai, C. and Hartmann, P. and Oddy, W. and Kusel, M. and Sly, P. and Holt, P. 2014. Anti-Infective Proteins in Breast Milk and Asthma-Associated Phenotypes During Early Childhood. Pediatric Allergy and Immunology. 25 (6): pp. 544-551.

Table 2 Allergic phenotypes in the 137 children included in the study

\begin{tabular}{|c|c|c|c|c|c|c|c|c|c|c|c|c|c|c|}
\hline & \multicolumn{2}{|c|}{6 months } & \multicolumn{2}{|c|}{1 year } & \multicolumn{2}{|c|}{2 year } & \multicolumn{2}{|c|}{3 years } & \multicolumn{2}{|c|}{4 years } & \multicolumn{2}{|c|}{5 years } & \multicolumn{2}{|c|}{10 years } \\
\hline & $\mathrm{n} / \mathrm{N}$ & $\%$ & $\mathrm{n} / \mathrm{N}$ & $\%$ & $\mathrm{n} / \mathrm{N}$ & $\%$ & $\mathrm{n} / \mathrm{N}$ & $\%$ & $\mathrm{n} / \mathrm{N}$ & $\%$ & $\mathrm{n} / \mathrm{N}$ & $\%$ & $\mathrm{n} / \mathrm{N}$ & $\%$ \\
\hline Atopy & $28 / 131$ & 21.4 & - & - & $58 / 131$ & 44.3 & - & - & - & - & $47 / 119$ & 39.5 & $69 / 84$ & 82.1 \\
\hline Eczema & $68 / 137$ & 49.6 & $52 / 137$ & 38.0 & $48 / 131$ & 36.6 & $37 / 127$ & 29.1 & $37 / 125$ & 29.6 & $35 / 122$ & 28.7 & $25 / 97$ & 25.8 \\
\hline Wheezing & - & - & $46 / 137$ & 33.6 & $40 / 131$ & 30.5 & $38 / 127$ & 29.9 & $33 / 125$ & 26.4 & $36 / 122$ & 29.5 & $11 / 96$ & 11.5 \\
\hline Asthma & - & - & - & - & - & - & - & - & - & - & $23 / 122$ & 18.9 & $14 / 95$ & 14.7 \\
\hline
\end{tabular}

n: number children with the condition; N: total number of children; Atopy: Skin prick test positive to one or more allergens (wheal size $>2$ mm); Eczema: Doctor diagnosis of eczema or atopic dermatitis experienced by child in last 12 months; Wheezing: parental opinion of whether child wheezed in last 12 months; Asthma: wheeze during last 12 months plus Doctor diagnosis of asthma beyond the second birthday 
Zhang, G and Lai, C and Hartmann, P. and Oddy, W and Kusel, M and Sly, P and Holt, P. 2014 . Anti-Infective Proteins in Breast Milk and Asthma-Associated Phenotypes During Early Childhood. Pediatric Allergy and Immunology. 25 (6): pp. 544-551.

Table 3 Concentrations $(\mathrm{g} / \mathrm{l})$ of milk proteins

\begin{tabular}{llccccccc}
\hline & & \multicolumn{3}{c}{ At 6 weeks } & \multicolumn{5}{c}{ At 6 months } \\
\hline \multirow{5}{*}{ sIgA } & $\mathrm{n}$ & Mean & SD & $\mathrm{n}$ & Mean & SD & $\mathrm{p}$ \\
& Right & 135 & 0.709 & 0.443 & 134 & 0.712 & 0.479 & \\
& Left & 136 & 0.620 & 0.390 & 133 & 0.710 & 0.475 & \\
& Average & 134 & 0.669 & 0.358 & 132 & 0.711 & 0.400 & 0.67 \\
& Right & 136 & 0.077 & 0.088 & 133 & 0.099 & 0.102 & \\
\multirow{5}{*}{ Lactoferrin } & Left & 135 & 0.071 & 0.078 & 131 & 0.127 & 0.154 & \\
& Average & 134 & 0.074 & 0.071 & 131 & 0.113 & 0.110 & $<0.001$ \\
& Right & 134 & 2.670 & 1.861 & 132 & 2.326 & 1.874 & \\
& Left & 135 & 2.526 & 1.896 & 130 & 1.900 & 1.363 & \\
& Average & 133 & 2.598 & 1.579 & 130 & 2.126 & 1.289 & $<0.001$ \\
& Right & 136 & 14.867 & 8.655 & 132 & 12.696 & 7.107 & \\
& Left & 135 & 15.497 & 21.248 & 129 & 11.310 & 6.229 & \\
& Average & 134 & 15.145 & 12.873 & 129 & 12.056 & 5.842 & $<0.001$ \\
\hline
\end{tabular}


Zhang, G. and Lai, C. and Hartmann, P. and Oddy, W. and Kusel, M. and Sly, P. and Holt, P. 2014. Anti-Infective Proteins in Breast Milk and Asthma-Associated Phenotypes During Early Childhood. Pediatric Allergy and Immunology. 25 (6): pp. 544-551.

Table 4 Adjusted geometric means (g/l) and 95\% confidence intervals of milk proteins collected at 6 weeks $(6 \mathrm{w})$ and 6 months $(6 \mathrm{~m})$, stratified by eczema assessed at 6 months, 1 year, 2 and 3 years of age; General linear models were employed for the analyses adjusted for gender, passive smoking and number of older children

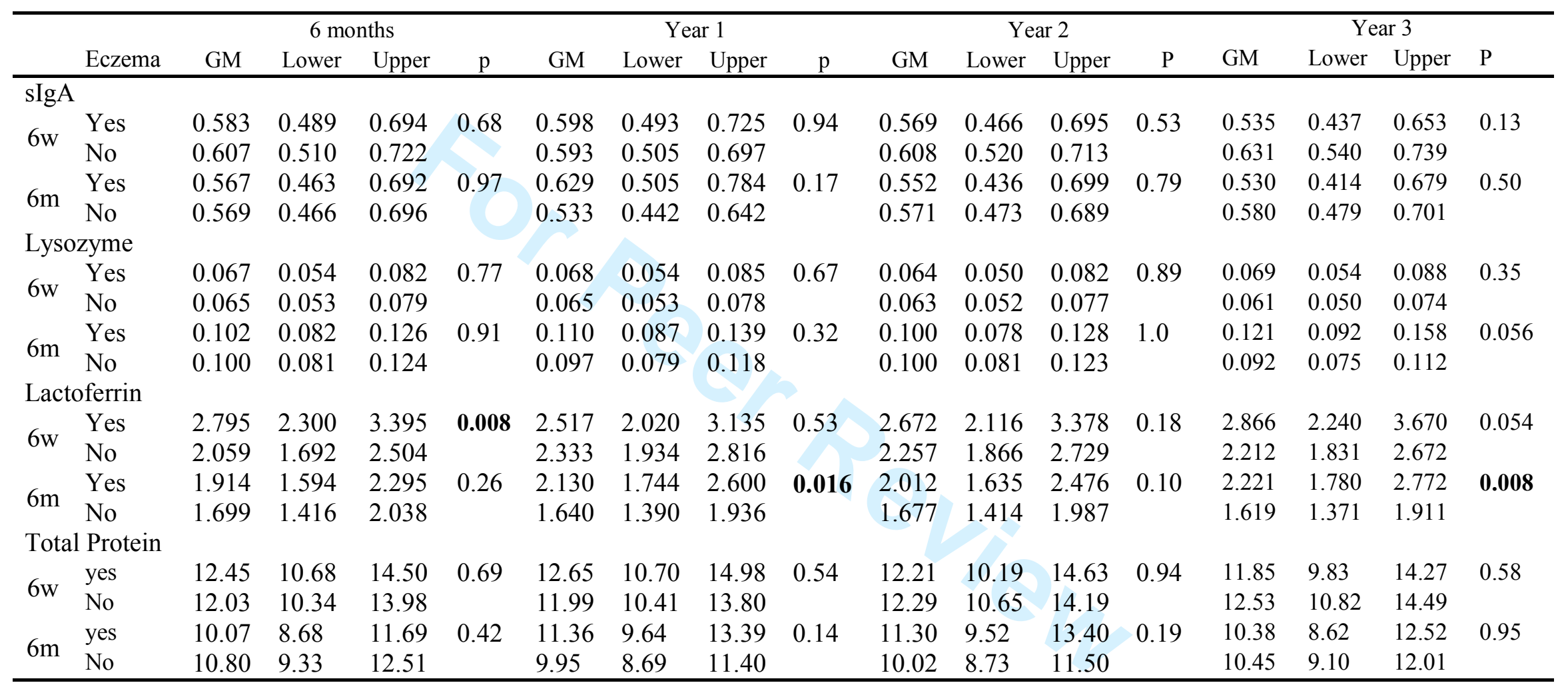


Zhang, G. and Lai, C. and Hartmann, P. and Oddy, W. and Kusel, M. and Sly, P. and Holt, P. 2014. Anti-Infective Proteins in Breast Milk and Asthma-Associated Phenotypes During Early Childhood. Pediatric Allergy and Immunology. 25 (6): pp. 544-551.

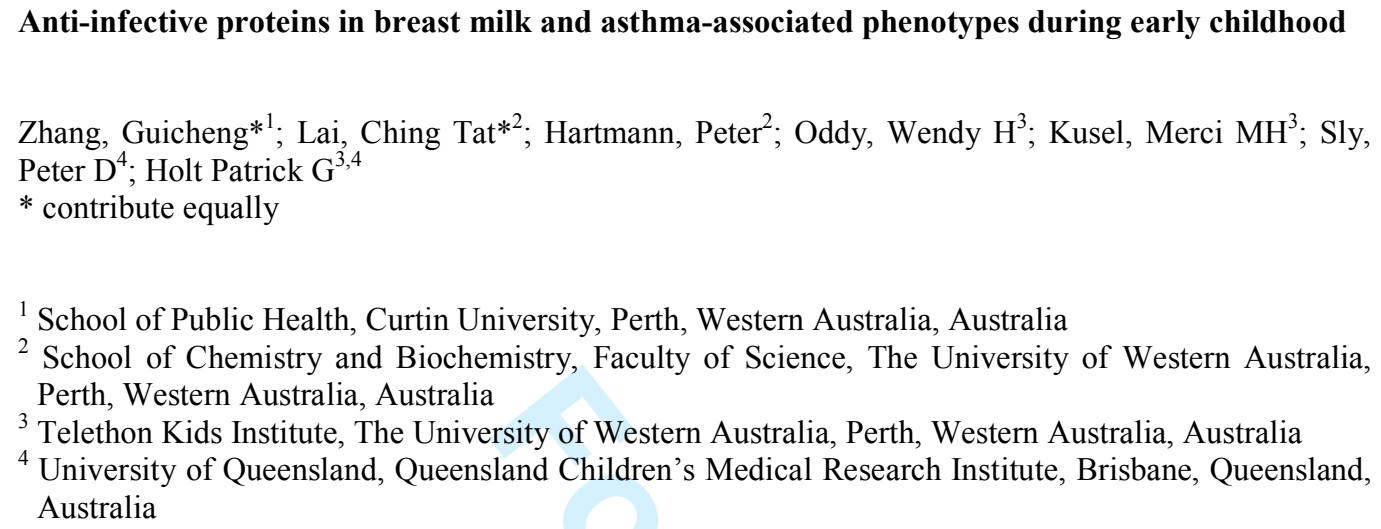

Zhang, Guicheng*1; Lai, Ching Tat*2; Hartmann, Peter ${ }^{2}$; Oddy, Wendy $\mathrm{H}^{3}$; Kusel, Merci $\mathrm{MH}^{3}$; Sly, Peter D ${ }^{4}$; Holt Patrick $\mathrm{G}^{3,4}$

* contribute equally

${ }_{2}^{1}$ School of Public Health, Curtin University, Perth, Western Australia, Australia

${ }^{2}$ School of Chemistry and Biochemistry, Faculty of Science, The University of Western Australia, Perth, Western Australia, Australia

${ }^{3}$ Telethon Kids Institute, The University of Western Australia, Perth, Western Australia, Australia

${ }^{4}$ University of Queensland, Queensland Children's Medical Research Institute, Brisbane, Queensland, Australia

Running title: Breast milk proteins and risk for atopy/asthma

| Corresponding Authors:

Prof Patrick G Holt

Professor P G Holt

Division of Cell Biology

Telethon Kids Institute

PO Box 855

West Perth WA 6872 Australia

Tel: $\quad+61894897838$

Email: Patrick.Holt@telethonkids.org.au

Marina.Stubbs@telethonkids.org.au

Dr Guicheng Zhang, School of Public Health, Curtin University

Email: brad.zhang@curtin.edu.au

Word Count; 3022 


\section{Abstract}

\section{Background}

The impact of breastmilk feeding on susceptibility to asthma in childhood is highly controversial, due in part to failure of the majority of studies in the area to adequately account for key confounders exemplified by respiratory infection history, plus the effects of recall bias.

\section{Methods}

As part of a prospective cohort study on the role of respiratory infections in asthma development in high-risk children, we measured the concentration of a panel of anti-infective proteins in maternal milk samples, and analysed associations between these and subsequent atopy-, infection- and asthma-related outcomes prospectively to age 10 years.

\section{Results}

We observed significant but transient inverse associations between the concentration of milk proteins and susceptibility to upper respiratory infections in year 1 only, and parallel but positive transient associations with early lower respiratory infections and atopy. No associations were seen with asthmarelated outcomes.

\section{Conclusions}

Breast milk feeding may influence the expression of inflammatory symptoms associated with respiratory infections and atopy in early life but these effects appear to be inconsistent and transient. The heterogeneous nature of breastfeeding effects suggests it may influence systemic immunoinflammatory function at several different levels. 
Zhang, G. and Lai, C. and Hartmann, P. and Oddy, W. and Kusel, M. and Sly, P. and Holt, P. 2014. Anti-Infective Proteins in Breast Milk and Asthma-Associated Phenotypes During Early Childhood. Pediatric Allergy and Immunology. 25 (6): pp. 544-551. 


\section{Introduction}

Breastfeeding is widely acknowledged to have protective effects against a range of health problems in infancy and childhood, as well as reducing risk for some chronic diseases that persist into-or-manifest de now in later life ${ }^{1}$. Until comparatively recently, allergy-associated syndromes including atopic asthma were paramount amongst the list of diseases reportedly susceptible to the protective effects of breastfeeding, 2,3 and recommendations for exclusive breastfeeding for the first 6 months of life have been a prominent feature of many official guidelines aimed at allergy prevention ${ }^{4,5}$.

However, a growing body of information derived from retrospective and (in particular) prospective birth cohort studies has questioned the validity of this paradigm. The relevant findings include observations linking early introduction of allergenic foods with decreased risk of subsequent food allergy ${ }^{6,7}$, the lack of evidence from the large scale ISAAC study for any protective effect of exclusive breastfeeding against eczema ${ }^{8}$, and suggestive evidence that in certain populations breastfeeding may even increase long term risk for atopy and asthma ${ }^{9,10}$.

The relationship between breastfeeding and asthma/allergic disease risk remains highly controversial. Complicating this debate is the growing realization that the majority of the available studies which have shaped current opinions in this area suffer from significant-methodological flaws that mitigate against reaching firm conclusions ${ }^{9,11}$. The protective effects of breastfeeding on infection and allergic conditions are known to be largely derived from the proteins of human milk ${ }^{12}$. Amongst the most important are secretory immunoglobulin A (sIgA), lysozyme and lactoferrin which are major whey proteins that make up approximately $40 \%$ of total protein in human milk which. These proteins are well known for their immune properties against a range of infections and diseases ${ }^{12}$. Together with 
other immune proteins in human milk, they assist infants to establish and strengthen their immunity against infections and diseases later in life ${ }^{13}$.

Our aim in the present study was to ascertain whether these protein components of breast milk have demonstrable activity in relation to protection of children against asthma and allergy. We have established a longitudinal cohort that provides a novel opportunity to investigate this question. The findings reported below are derived from a subgroup of subjects from the Perth Childhood Asthma Study (CAS) cohort ${ }^{14-17}$, the design of which enables examination of this issue from a unique perspective. Notably, this study had a primary focus on respiratory infection and as such included physician verification and clinical assessment of all parent-reported putative infection events within the first 5 years of life. Moreover, the subgroup from this cohort utilized for these analyses was restricted to children whose mothers provided breast milk samples, and the study mothers were closely monitored and supported by the clinical team including collection and analysis of breast milk samples at 6 weeks and 6 months post partum. In addition to physician-monitoring of each respiratory infection event in these children, objective assessment of allergy-associated and asthma-associated clinical phenotypes was performed by the same-clinical team-at $6 \mathrm{mths}$ and annually to age 5 years, with an-additional followup at age 10 years. This approach enabled collection of a unique data set that enablesfor examination of the question of whether breast feeding influences allergy/asthma susceptibility from a perspective not previously considered in detail i.e. whether differences in the concentration of key protein constituents in milk (milk "quality") were associated with downstream-variations in tevels of disease risk amongst recipients. The milk constituents chosen for these analyses were secretory immunoglobulin A (sIgA), lysozyme and lactoferrin, in addition to total protein. 


\section{Methodology}

\section{Subjects}

One hundred and forty 142 mother:-and-infants pairs participating infrom the Childhood AsthmaCAS Studycohort ${ }^{16,17}$ (CAS) were included in the milk study. Subjects in this study were part of an ongoing prospective birth cohort, as previously described ${ }^{16,17}$-TBriefly, the cohort was initiated in 1996 and continued from 1996 to 1998 in the Perth metropolitan area, all subjects were enrolled antenatally and classified as having an atopic family history based on a standard questionnaire and a positive doctor's diagnosis of asthma, hay fever, or atopic dermatitis for 1 or both parents. The cohort has been follow up at 6 weeks, 6 months, 1, 2, 3, 4, 5 and 10 years with comprehensive assessment of allergic and asthmatic phenotype ${ }^{15-17}$ phenotypes $^{15-17}$.

Breastfeeding history was monitored through dietary questionnaire administered at the 6 weeks' and 6 months' visits and breast milk samples were collected at these visits. Infectious episodes were prospectively recorded throughout the first 5 years of each-child's life-with a daily parental diary; parents were trained to summon the clinical team at every incidence of suspected respiratory infection, enabling symptom verification during the ensuing home visits by the clinical team. Acute respiratory infections (ARIs) were subclassified as lower respiratory infection (LRI), wheezy lower respiratory infection (wLRI) and upper respiratory infection (URI) as detailed in the online supplement. Any episode with runny/blocked nose or dry cough was classified as a URI. Episodes that were associated with wheeze, or cough and rattly chest were considered to be LRI. Rattle/rattly chest was described as moist, wet noisy breath sounds from the child's chest. Wheeze was defined as a high-pitched whistling sound heard coming from the chest, on expiration. LRI were further classified into wLRI and nonwheezy LRI based on the presence of any wheeze reported by the parent or family doctor.Skin prick tests to a panel of ingested and aero- allergens were performed at 6 months, 2 years, 5 and 10 years to 
define atopy. The subjects were examined for eczema on each of the scheduled followup visits as well as during all home visits for respiratory episodes during the first 5 years. Eczema was defined as doctor diagnosis of eczema or atopic dermatitis experienced by child in last 12 months. Wheezing is the parental opinion of whether child wheezed in last 12 months. Asthma was defined as wheeze during last 12 months (parent opinion) plus Doctor diagnosis of asthma beyond the second birthday.

\section{Protein measurements}

The milk samples were stored at $-20^{\circ} \mathrm{C}$ prior to use for the studyafter collection. Before any biochemical analysis, thawed milk samples were thawed at room temperature, mixed and centrifuged at 10000 RPM for 10 minutes. The tube was sliced to remove the fat layer. The fat layer (the cloudy layer) was removed by slicing the tube at the bottom of the fat layer. The sIgA, lysozyme, lactoferrin and total protein were assayed in the defatted milk.

\section{Lysozyme analysis}

Lysozyme in the samples was determined-measured by a simple assay that was modified frommodification of Selsted \& Martinez ${ }^{18}$. The assay measured the loss of turbidity due to the lysis of Micrococcus lysodeikticus. The assay was modified that the reduction of the incubation time from 18 hours to 6 hours was found to still provide an effective of standard range for the assay.

\section{Lactoferrin and SIgA analysis}

Lactoferrin and sIgA in the samples was determined by ELISA that was adapted from Tijssen ${ }^{19}$. In the sIgA ELISA, three antibodies were used: primary antibody (Rabbit anti-human - $\operatorname{Ig} A \operatorname{Ig} G, 6000$ fold in PBS, DAKO), secondary antibody (Mouse anti- human - IgA IgG, 5000 fold in PBS/Tween containing 
Zhang, G. and Lai, C. and Hartmann, P. and Oddy, W. and Kusel, M. and Sly, P. and Holt, P. 2014. Anti-Infective Proteins in Breast Milk and Asthma-Associated Phenotypes During Early Childhood. Pediatric Allergy and Immunology. 25 (6): pp. 544-551.

1g/1 BSA, DAKO) and third antibody (Goat anti- mouse - $\operatorname{IgG} \operatorname{IgG}$ conjugated to horseradish peroxidase, 4000 fold in PBS/Tween containing $1 \mathrm{~g} / 1$ BSA, Bio-Rad). Standard $\operatorname{IgA}$ from human colostrum was prepared in PBS/Tween (range from 0 to $0.4 \mathrm{mg} / \mathrm{ml}$, Sigma). Milk samples were diluted 5000 fold in PBS/Tween for analysis.

In the lactoferrin ELISA, two antibodies were used: primary antibody (anti- human lactoferrin, 4000 fold in PBS, ICN) and second antibody (anti- human lactoferrin conjugated to HRP was diluted 5,000 fold in PBS/Tween containing $1 \mathrm{~g} / 1 \mathrm{BSA}, \mathrm{ICN})$. Human lactoferrin standard was prepared in PBS/Tween (range from 0 to $0.02 \mathrm{mg} / \mathrm{ml}$, ICN). Milk samples were diluted 200,000 fold in PBS Tween.

\section{Total protein}

Total protein in the samples-was determined by a protein assay that measured the binding of the protein dye (Bio-Rad) to the primarily basic and aromatic amino acid residues of the proteins. Further assay details appear in the online supplement The dye was diluted 1:4 v/v and filtered with Whatman $\# 1$ filter paper prior to use. To-overcome the problems inherent in the choice of a millk standard, the protein concentration of an aliquot of mature breast milk was determined by the Kjeldahl procedure ${ }^{20,21}$. The remaining sample was then diluted with double deionised water to provide a range of standards ( 0 to 1g/1). The defatted mill samples were diluted 30 fold for the assay. Standards and diluted samples

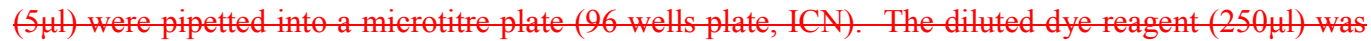
added and mixed with the plate mixer (WellMix2, Australia). The absorbance of each sample/standard was measure at $620 \mathrm{~nm}$ with the Multiskan plate reader until the maximum absorbance was reached in approximately 20 minutes. 


\section{Statistical analysis}

Levels of sIgA, lysozyme, lactoferrin and total pProtein levelss were log-transformed to have an approximately normal distribution. As the number of infectious episodes such as URI and LRI was a count variable Poison regression was employed to investigate the associations between levels of sIgA, lysozyme, lactoferrin and totalmilk proteins and the incidence of respiratory infections-during first 3 years of life. In order to examine the associations of breast milk proteins with binary outcomes such as atopy (defined by skin prick tests), eczema, wheezing and asthma at the different time points-we compared the levels of these between the two scenarios of these binary outcomes using general linear models after adjusting for gender, passive smoking and number of older siblings. All the analyses were conducted using IBM SPSS Statistics 20.

\section{Results}

In this subcohort there were initially 142 infants. Five infants who were partly fed with formula were subsequently excluded from the analyses. Table 1 shows the characteristics of 137 children included in the present study and the remaining children in the longitudinal cohorts. The children for this study appeared to have lower prevalence of smoking exposure and childcare attendance at age 1, compared with the remaining children. Table 2 shows prevalence of these conditions in the 137 children who completed the study.

\section{Levels of breast milk proteins}

Within individual milk donors, the concentrations of $\operatorname{sg} \mathrm{A}$, lactoferrin, lysozyme and total protein varied between breasts at both six weeks and six months of lactation (Table 3). The range in the concentrations of sIgA, lactoferrin, lysozyme and total protein from each breast at both six weeks and six months of lactation was large (Table 3). At six weeks of lactation, the mean concentrations of the 
right and left breasts for sIgA were $(0.67 \pm 0.36 \mathrm{~g} / \mathrm{l})$, lactoferrin was $(2.59 \pm 1.58)$, lysozyme was $(0.07 \pm$ $0.07 \mathrm{~g} / \mathrm{l})$ and total protein was $(15.1 \pm 12.87 \mathrm{~g} / \mathrm{l})$ respectively. At six months of lactation, the mean concentrations of the right and left breasts for $\operatorname{sigA}$ were $(0.71 \pm 0.40 \mathrm{~g} / 1)$, lactoferrin was $(2.13 \pm 1.29)$, lysozyme was $(0.11 \pm 0.11 \mathrm{~g} / \mathrm{l})$ and total protein was $(12.1 \pm 5.84 \mathrm{~g} / \mathrm{l})$ respectively. There were significant changes in the concentration of sIgA, lactoferrin, lysozyme and total protein in milk from both breasts, except sIgA (left breast only), between six weeks and six months of lactation (data not shown). All subsequent analyses utilized mean data from two breasts for each mother in the study.

\section{Atopy}

We investigated associations between the concentrations of breast milk proteins with atopy defined by skin prick tests (SPT) at age 6 months, 2 and 5 years. We chose to measure atopy status at multiple time points in light of our early demonstration ${ }^{14}$ that IgE production is commonly time during the preschool years. The levels of milk proteins in the study population are shown in Figure 1, stratified by atopy outcomes in their offspring at these three time points. sIgA concentrations in milk samples collected at 6 months were significantly higher $(p=0.019)$ in the mothers whose infants developed atopy by this age, compared with mothers of infants without atopy (Fig 1a). The 6 month lactoferrin levels were also significantly higher $(\mathrm{p}=0.022)$ in this group (Fig $1 \mathrm{c})$, as well as 6 week $(p=0.028)$ and 6 month $(p=0.009)$ total protein levels (Fig 1d). Similar effects were observed with respect to total protein levels in maternal milk samples (Fig 1d), which were significantly higher at both 6 weeks $(p=0.001)$ and 6 months $(p=0.012)$ in mothers whose infants developed atopy by age 2. It appeared that this relationship persisted up to outcome age 2 years but was lost by 5 years; additional regression modeling of 10 year data also did not demonstrate significant associations between milk protein content and atopy outcomes. 


\section{Eczema}

Eczema was assessed at 6 months, 1, 2, 3, 4, 5 and 10 yearseach followup of in the-longitudinal cohort. We compared levels of individual breast milk proteins in offspring with and without eczema at these time points after adjusting for gender, number of older children and passive smoking, and results out to year 3 are shown in Table 4 (as above, unadjusted data yielded similar results). Positive associations were observed between Lactoferrin levels and eczema outcomes at 6 months and 1 and 3 years, but not beyond these time points (not shown) with an exception that a marginal effect of milk lysozyme at 6 months on current eczema at age 10 was also observed. $(\mathrm{p}=0.048)$.

\section{Respiratory infections}

We assessed the-associations between levels of maternal maternal-milk proteins and the -risk in their offspring for respiratory infections in the first 3 years-of life, using Poisson regression models and adjusting for gender, passive smoking and number of older ehildrensiblings. Generally, the presence of high levels of anti-infective proteins were associated with reduced frequency of URIs (IRR $<1)$ in the first two years of life (Supplementary Table 1). sIgA levels were associated with a decreased risk for URIs in the first year of life at a significance of $p=0.035$ and 0.079 for milk samples collected at 6 weeks and 6 months, respectively, and similarly for Lactoferrin levels in 6 month samples $(\mathrm{p}=0.008)$. With respect to year 2 URI outcomes, 6 week IgA and 6 month Lactoferrin levels were also significantly associated with a decreased risk for URI ( $\mathrm{p}$ - = These associations diminished beyond year 2 .

No associations were observed that were consistent with parallel milk-mediated protection against the spread and/or intensification of infections in the lower respiratory tract. Instead, high levels of Lactoferrin and/or Lysozyme in early milk samples were paradoxically associated with increased risk 
for wheezing lower respiratory infections, but only during the first year of life (Supplementary Table

2).

\section{Wheezing and asthma}

Current wheezing was evaluated at ages $1,2,3,4,5$ and 10 yearseach annual visit and asthma was defined at ages 3, 4, 5 and 10 years. No significant associations were found between the concentrations of breast milk proteins with these phenotypes employing either adjusted or raw data utilized above (not shown). In followup analyses we also tested multiple regression models in which qualitative and quantitative respiratory tract infection history over the first two years of life were included as additional confounders, and again could not identify any significant linkages between milk protein levels and asthma-associated phenotypes (data not shown).

\section{Discussion}

The focus of studies in the Perth Childheod Asthma Study (CAS) birth cohort is on identification of factors driving asthmathe pathogenesis of asthma-during childhood. Our previous investigations in this cohort have identified early allergic sensitization and early_oncomitant respiratory tract infections_; particularly during the first two years of life, as major asthma risk factors ${ }^{16}$. These can operate independently to drive asthma development, however the highest level of risk is observed in children who experience both sensitization to perennial aeroallergens-and respiratory tract infections concomitantly during this period $^{14}$. The initial diagnosis of asthma in the cohort was made at age 5 years ${ }^{16}$, but more recently it was shown that these effects carry through to at least 10 years ${ }^{15}$. It is additionally noteworthy that the relevant infections are those that spread to the lower respiratory tract and attain sufficient severity to trigger symptoms of wheeze and/or fever, whereas infections that remain restricted to the upper respiratory tract are benign in this context ${ }^{15,16}$. 
It is reasonable to consider breast milk intake as a potential factor that may modulate asthma risk in

CAS cohort subjects for a number of reasons, in particular (i) an earlier literature suggesting that breast milk feeding can protect against allergic sensitization (e.g. ${ }^{3}$ ); (ii) the well established role of breastfeeding in protecting infants against both enteric and respiratory infections ${ }^{22}$; and (iii) the reports from earlier observational studies linking exclusive breast feeding with reduced rates of subsequent wheeze $\mathrm{e}^{23-25}$.

These claims have biological plausibility at several levels. Notably, it has been established that innate and adaptive immune functions in all infants are in a functionally quiescent state at birth ${ }^{26-28}$, and mature postnatally in response to environmental microbial stimulation, especially from commensal organisms in the gastrointestinal tract (reviewed ${ }^{29,30}$ ) but also from common childhood infections (the "Hygiene Hypothesis" ${ }^{31}$ ). However, as noted above, certain categories of severe respiratory infections appear to have the opposite effects in relation to risk of asthma, likely due in part to direct inflammatory damage to developing lung function extrinsic to any influence on immune system maturation $^{32}$.

The kinetics of postnatal immune maturation is eonstitutively-sluggish in a significant subset of children at high risk of developing atopy/asthma ${ }^{33,34}$, and hence factors that modulate exposure to common and relatively benign childhood infections, and/or patterns of colonization with commensal microflora, may influence this process in ways that cannot be predicted. In this regard it is noteworthy that a growing literature has implicated breast milk feeding as an important modulator of quantitative and qualitative aspects of postnatal bacterial colonization of the GIT ${ }^{35-37}$. 
These complexities may explain some of the disparities in the published-literature on relationships between breast feeding and future atopy/asthma outcomes, and likewise some of the apparent contradictions in our findings above from the CAS cohort. Notably, a clear finding in these subjects was the inverse association between levels of the anti-infectives IgA and Lactoferrin in milk and risk for upper respiratory infections in year 1, which extended into year 2 (Table 4). However, these protective effects were not seen with respect to the lower respiratory tract, and instead levels of milk proteins (in this case Lactoferrin and Lysozyme) were positively associated with risk for wheezing infections (Table 5). Similar positive relationships were observed between levels of milk proteins and early atopic outcomes measured as either SPT reactivity (Figs 1 and 2) or eczema Table 3; Fig 3); in both cases these effects were transient and were not generally seen beyond age 2 years. In this regard we have previously reported that increased amounts of omega- 3 fatty acids in maternal milk at 6 weeks protected against eczema at 6 months, but this protection did not continue to later ages ${ }^{38}$.

The dichotomous nature of our findings cannot be fully explained, but some possibilities can be considered. Firstly, breast milk feeding-associated protection against relatively mild URI at/around the time of infancy is not unexpected and is consistent with what is known re the anti-infective properties of maternal milk mediated via direct effects of anti-microbial molecules on incoming pathogens.

However the reasons for dissociation between these URI effects and those relating to susceptibility to atopy and/or the spread of infections to the LRI are unclear. Possible explanations include (i) these severe LRI events may reflect higher pathogen loads that are beyond the range that is potentially controllable by milk-born anti-infectives; (ii) resistance to infection spread/intensification and to atopic sensitization in infants may depend upon defence mechanisms that are discrete from those that protect against URI, in particular cellular immune mechanisms that are reliant upon "endogenous" maturation- 
inducing microbial signals, particularly from GIT commensals, colonization with which is likely influenced by milk-born anti-infectives. However it is not feasible to directly test these possibilities with the available data.

The most clearcut finding in our study is the lack of any-discernible milk protein quality-associated effects on asthma-related outcomes that persist beyond early childhood. It is pertinent to reiterate that these outcomes have been shown to be highly sensitive to early history of both atopy and LRI in this cohort $^{14-16}$, which as noted above are transiently influenced by breast milk quality, but apparently not to a degree which influences subsequent susceptibility to asthma. Our findings are thus consistent with the growing body of evidence suggesting that the long-term benefits of breast milk feeding in relation to these atopy- and asthma-associated phenotypes are limited ${ }^{6-10}$ but we cannot completely exclude effects based on our study because our sample size is small. We have described all statistical analyses carried out and did not make multiple test corrections because (i) they can be overly conservative and may inflate type II errors and (ii) our analyses were based on an a priori hypothesis ${ }^{39}$.

In conclusion it is relevant to acknowledge the limitations of this study. Firstly regarding the lack of association between wheezing/asthma and levels of milk proteins we acknowledge the possible type II errors due to relatively small sample size, which also precluded further sub-group analysis on the effects of milk proteins on other outcomes. However, this is a longitudinal cohort with wheezing phenotypes comprehensively investigated, which is superior to a cross-sectional study. There were $\underline{\text { strong correlations between levels of individual proteins and the total milk proteins. We, therefore, }}$ $\underline{\text { could not further clarify the effects of individual proteins in this cohort. Additionally, While-while }}$ unlike previous investigations we have been able to include comprehensive data relating to the potential confounding effects of infection history in regression models of milk-related effects on 
Zhang, G. and Lai, C. and Hartmann, P. and Oddy, W. and Kusel, M. and Sly, P. and Holt, P. 2014. Anti-Infective Proteins in Breast Milk and Asthma-Associated Phenotypes During Early Childhood. Pediatric Allergy and Immunology. 25 (6): pp. 544-551.

354 asthma-associated outcomes, this remains a relatively small study, and larger sample sizes with greater
355 statistical power may be required to finally resolve this issue. Additionally Also, our study population
356 are all at high genetic risk for atopy/asthma and thus representative of $40-45 \%$ of the pediatric 357
Formatted: Font: Font color: Red, (Asian) Chinese (PRC), (Other) English (Australia) 
Zhang, G. and Lai, C. and Hartmann, P. and Oddy, W. and Kusel, M. and Sly, P. and Holt, P. 2014. Anti-Infective Proteins in Breast Milk and Asthma-Associated Phenotypes During Early Childhood. Pediatric Allergy and Immunology. 25 (6): pp. 544-551.

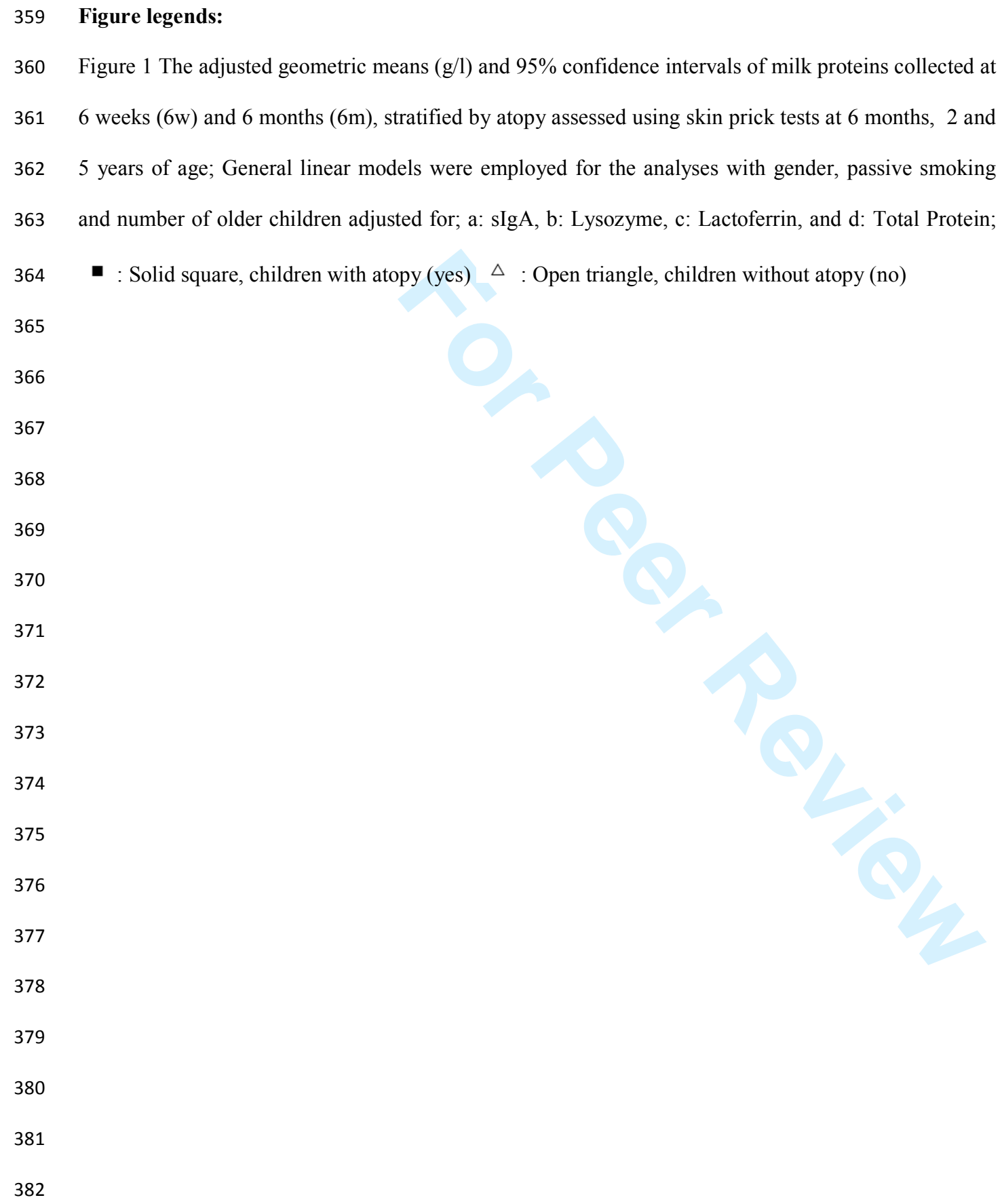




\section{Page 41 of 58}

Zhang, G. and Lai, C. and Hartmann, P. and Oddy, W. and Kusel, M. and Sly, P. and Holt, P. 2014. Anti-Infective Proteins in Breast Milk and Asthma-Associated Phenotypes During Early Childhood. Pediatric Allergy and Immunology. 25 (6): pp. 544-551. 


\section{References}

1. Dieterich CM, Felice JP, O'Sullivan E, Rasmussen KM. Breastfeeding and health outcomes for the mother-infant dyad. Pediatr Clin North Am 2013;60:31-48.

2. Oddy WH, de Klerk NH, Sly PD, Holt PG. The effects of respiratory infections, atopy, and breastfeeding on childhood asthma. European Respiratory Journal 2002;19:899-905.

3. Oddy WH, Holt PG, Sly PD, et al. Association between breast feeding and asthma in 6 year old children: findings of a prospective birth cohort study. BMJ (Clinical research ed) 1999;319:815-9.

4. NHMRC. Eat for Health: Australian Dietary Guidelines. In: Australia NHMRCo, ed.: National Health and Medical Research Council of Australia; 2013:36.

5. Kramer MS, Kakuma R. The optimal duration of exclusive breastfeeding: a systematic review. Adv Exp Med Biol 2004;554:63-77.

6. Du Toit G, Katz Y, Sasieni P, et al. Early consumption of peanuts in infancy is associated with a low prevalence of peanut allergy. J Allergy Clin Immunol 2008;122:984-91.

7. Koplin JJ, Osborne NJ, Wake M, et al. Can early introduction of egg prevent egg allergy in infants? A population-based study. J Allergy Clin Immunol 2010;126:807-13.

8. Flohr C, Nagel G, Weinmayr G, et al. Lack of evidence for a protective effect of prolonged breastfeeding on childhood eczema: lessons from the International Study of Asthma and Allergies in Childhood (ISAAC) Phase Two. Br J Dermatol 2011;165:1280-9.

9. Sears MR, Greene JM, Willan AR, et al. Long-term relation between breastfeeding and development of atopy and asthma in children and young adults: a longitudinal study. Lancet 2002;360:901-7.

10. Wright AL, Holberg CJ, Taussig LM, Martinez FD. Factors influencing the relation of infant feeding to asthma and recurrent wheeze in childhood. Thorax 2001;56:192-7. 
11. Matheson MC, Allen KJ, Tang ML. Understanding the evidence for and against the role of breastfeeding in allergy prevention. Clin Exp Allergy 2012;42:827-51.

12. Lonnerdal B. Bioactive proteins in human milk: mechanisms of action. The Journal of pediatrics 2010;156:S26-30.

13. Walker A. Breast milk as the gold standard for protective nutrients. The Journal of pediatrics 2010;156:S3-7.

14. Holt P, Rowe J, Kusel M, et al. Towards improved prediction of risk for atopy and asthma amongst preschoolers: a prospective cohort study. J Allergy Clin Immunol 2010;125:645-51.

15. Kusel M, Kebadze T, Johnston S, Holt P, Sly P. Febrile respiratory illnesses in infancy and atopy are risk factors for persistent asthma and wheeze. European Respiratory Journal 2012;39:876-82.

16. Kusel MM, de Klerk NH, Kebadze T, et al. Early-life respiratory viral infections, atopic sensitization, and risk of subsequent development of persistent asthma. Journal of Allergy and Clinical Immunology 2007;119:1105-10.

17. Kusel MMH, de Klerk NH, Holt PG, Kebadze T, Johnston SL, Sly PD. Role of respiratory viruses in acute upper and lower respiratory tract illness in the first year of life - A birth cohort study. Pediatric Infectious Disease Journal 2006;25:680-6.

18. Selsted ME, Martinez RJ. A simple and ultrasensitive enzymatic assay for the quantitative determination of lysozyme in the picogram range. Anal Biochem 1980;109:67-70.

19. Tijssen P. Laboratory techniques in biochemistry and molecular biology. In: Burdon RHavK, P.H., ed. Practice and theory of immunoessays. New York: Elsevier; 1985.

20. Atwood CS, Hartmann PE. Collection of fore and hind milk from the sow and the changes in milk composition during suckling. J Dairy Res 1992;59:287-98.

21. Hambraeus L, Lonnerdal B, Forsum E, Gebre-Medhin M. Nitrogen and protein components of human milk. Acta Paediatr Scand 1978;67:561-5. 
22. Paramasivam K, Michie C, Opara E, Jewell AP. Human breast milk immunology: a review. Int J Fertil Womens Med 2006;51:208-17.

23. Aberg N, Engstrom I, Lindberg U. Allergic diseases in Swedish school children. Acta Paediatr Scand 1989;78:246-52.

24. Chandra RK. Five-year follow-up of high-risk infants with family history of allergy who were exclusively breast-fed or fed partial whey hydrolysate, soy, and conventional cow's milk formulas. J Pediatr Gastroenterol Nutr 1997;24:380-8.

25. Kaufman HS, Frick OL. The development of allergy in infants of allergic parents: a prospective study concerning the role of heredity. Ann Allergy 1976;37:410-5.

26. Levy O. Innate immunity of the newborn: basic mechanisms and clinical correlates. Nat Rev Immunol 2007;7:379-90.

27. Siegrist CA. Vaccination in the neonatal period and early infancy. Int Rev Immunol 2000;19:195-219.

28. Holt PG. Postnatal maturation of immune competence during infancy and childhood [Review]. Pediatric Allergy and Immunology 1995;6:59-70.

29. Holt PG. Environmental factors and primary T-cell sensitization to inhalant allergens in infancy: reappraisal of the role of infections and air pollution [Review]. Pediatric Allergy and Immunology 1995;6:1-10.

30. Rook GA, Stanford JL. Give us this day our daily germs. Immunology Today 1998;19:113-6.

31. Strachan DP. Hay fever, hygiene, and household size. Br Med J 1989;299:1259-60.

32. Holt PG, Sly PD. Viral Infections and atopy in asthma pathogenesis: new rationales for asthma prevention and treatment. Nature Medicine 2012;18:726-35.

33. Holt PG, Clough JB, Holt BJ, et al. Genetic 'risk' for atopy is associated with delayed postnatal maturation of T-cell competence. Clinical and Experimental Allergy 1992;22:1093-9. 
Zhang, G. and Lai, C. and Hartmann, P. and Oddy, W. and Kusel, M. and Sly, P. and Holt, P. 2014. Anti-Infective Proteins in Breast Milk and Asthma-Associated Phenotypes During Early Childhood. Pediatric Allergy and Immunology. 25 (6): pp. 544-551.

\begin{abstract}
479 34. Prescott SL, Macaubas C, Smallacombe T, Holt BJ, Sly PD, Holt PG. Development of allergen-
480 specific T-cell memory in atopic and normal children. Lancet 1999;353:196-200.

481 35. Favier CF, de Vos WM, Akkermans AD. Development of bacterial and bifidobacterial 482 communities in feces of newborn babies. Anaerobe 2003;9:219-29.

483 36. Meyers CA, Hess KR, Yung WK, Levin VA. Cognitive function as a predictor of survival in patients with recurrent malignant glioma. J Clin Oncol 2000;18:646-50.


Zhang, G and Lai, C and Hartmann, P. and Oddy, W. and Kusel, M and Sly, P and Holt, P. 2014. Anti-lnfective Proteins in Breast Milk and Asthma-Associated Phenotypes During Early Childhood. Pediatric Allergy and Immunology. 25 (6): pp. 544-551.

Table 1 The comparison of the 137 children and the remaining children in the longitudinal cohort

\begin{tabular}{lccc}
\hline & $\begin{array}{c}\text { 137 children for milk protein analysis } \\
\mathrm{n} / \mathrm{N}(\%)\end{array}$ & $\begin{array}{c}\text { Remaining children } \\
\mathrm{n} / \mathrm{N}(\%)\end{array}$ & $\mathrm{p}$ \\
\hline Males & $83 / 137(60.6)$ & $63 / 124(50.8)$ & 0.11 \\
Maternal atopy history & $106 / 135(78.5)$ & $71 / 89(79.8)$ & 0.82 \\
Paternal atopy history & $92 / 135(68.1)$ & $59 / 89(66.3)$ & 0.77 \\
Exposure to passive smoking at age 1 & $19 / 134(14.2)$ & $25 / 93(26.9)$ & 0.017 \\
Exposure to passive smoking at age 5 & $13 / 122(10.7)$ & $17 / 76(22.4)$ & 0.025 \\
Childcare attendance at age 1 & $32 / 134(23.9)$ & $34 / 93(36.6)$ & 0.039 \\
Childcare attendance at age 5 & $52 / 129(40.3)$ & $45 / 91(49.5)$ & 0.18 \\
Asthma at age 5 & $23 / 122(18.9)$ & $12 / 76(15.8)$ & 0.58 \\
\hline
\end{tabular}


Zhang, G. and Lai, C. and Hartmann, P. and Oddy, W. and Kusel, M. and Sly, P. and Holt, P. 2014. Anti-Infective Proteins in Breast Milk and Asthma-Associated Phenotypes During Early Childhood. Pediatric Allergy and Immunology. 25 (6): pp. 544-551.

Table 2 Allergic phenotypes in the 137 children included in the study

\begin{tabular}{|c|c|c|c|c|c|c|c|c|c|c|c|c|c|c|}
\hline & \multicolumn{2}{|c|}{6 months } & \multicolumn{2}{|c|}{1 year } & \multicolumn{2}{|c|}{2 year } & \multicolumn{2}{|c|}{3 years } & \multicolumn{2}{|c|}{4 years } & \multicolumn{2}{|c|}{5 years } & \multicolumn{2}{|c|}{10 years } \\
\hline & $\mathrm{n} / \mathrm{N}$ & $\%$ & $\mathrm{n} / \mathrm{N}$ & $\%$ & $\mathrm{n} / \mathrm{N}$ & $\%$ & $\mathrm{n} / \mathrm{N}$ & $\%$ & $\mathrm{n} / \mathrm{N}$ & $\%$ & $\mathrm{n} / \mathrm{N}$ & $\%$ & $\mathrm{n} / \mathrm{N}$ & $\%$ \\
\hline Atopy & $28 / 131$ & 21.4 & - & - & $58 / 131$ & 44.3 & & -1 & - & - & $47 / 119$ & 39.5 & $69 / 84$ & 82.1 \\
\hline Eczema & $68 / 137$ & 49.6 & $52 / 137$ & 38.0 & $48 / 131$ & 36.6 & $37 / 127$ & 29.1 & $37 / 125$ & 29.6 & $35 / 122$ & 28.7 & $25 / 97$ & 25.8 \\
\hline Wheezing & - & - & $46 / 137$ & 33.6 & $40 / 131$ & 30.5 & $38 / 127$ & 29.9 & $33 / 125$ & 26.4 & $36 / 122$ & 29.5 & $11 / 96$ & 11.5 \\
\hline Asthma & - & - & - & - & - & - & & - & - & - & $23 / 122$ & 18.9 & $14 / 95$ & 14.7 \\
\hline
\end{tabular}

n: number children with the condition; N: total number of children; Atopy: Skin prick test positive to one or more allergens (wheal size $>2$ mm) Eczema: Doctor diagnosis of eczema or atopic dermatitis experienced by child in last 12 months; Wheezing: parental opinion of whether child wheezed in last 12 months; Asthma: wheeze during last 12 months plus Doctor diagnosis of asthma beyond the second birthday 
Zhang, G. and Lai, C and Hartmann, P. and Oddy, W and Kusel, M. and Sly, P and Holt, P. 2014. Anti-Infective Proteins in Breast Milk and Asthma-Associated Phenotypes During Early Childhood. Pediatric Allergy and Immunology. 25 (6): pp. 544-551.

Table 3 Concentrations $(\mathrm{g} / \mathrm{l})$ of milk proteins

\begin{tabular}{llccccccc}
\hline & & \multicolumn{3}{c}{ At 6 weeks } & \multicolumn{5}{c}{ At 6 months } \\
\hline \multirow{5}{*}{ sIgA } & $\mathrm{n}$ & Mean & SD & $\mathrm{n}$ & Mean & SD & $\mathrm{p}$ \\
& Right & 135 & 0.709 & 0.443 & 134 & 0.712 & 0.479 & \\
& Left & 136 & 0.620 & 0.390 & 133 & 0.710 & 0.475 & \\
& Average & 134 & 0.669 & 0.358 & 132 & 0.711 & 0.400 & 0.67 \\
& Right & 136 & 0.077 & 0.088 & 133 & 0.099 & 0.102 & \\
\multirow{5}{*}{ Lactoferrin } & Left & 135 & 0.071 & 0.078 & 131 & 0.127 & 0.154 & \\
& Average & 134 & 0.074 & 0.071 & 131 & 0.113 & 0.110 & $<0.001$ \\
& Right & 134 & 2.670 & 1.861 & 132 & 2.326 & 1.874 & \\
\multirow{5}{*}{ Total protein } & Left & 135 & 2.526 & 1.896 & 130 & 1.900 & 1.363 & \\
& Average & 133 & 2.598 & 1.579 & 130 & 2.126 & 1.289 & $<0.001$ \\
& Right & 136 & 14.867 & 8.655 & 132 & 12.696 & 7.107 & \\
& Left & 135 & 15.497 & 21.248 & 129 & 11.310 & 6.229 & \\
& Average & 134 & 15.145 & 12.873 & 129 & 12.056 & 5.842 & $<0.001$ \\
\hline
\end{tabular}


Zhang, G. and Lai, C. and Hartmann, P. and Oddy, W. and Kusel, M. and Sly, P. and Holt, P. 2014. Anti-Infective Proteins in Breast Milk and Asthma-Associated Phenotypes During Early Childhood. Pediatric Allergy and Immunology. 25 (6): pp. 544-551.

Table 4 Adjusted geometric means ( $\mathrm{g} / \mathrm{l})$ and $95 \%$ confidence intervals of milk proteins collected at 6 weeks $(6 \mathrm{w})$ and 6 months $(6 \mathrm{~m})$, stratified by eczema assessed at 6 months, 1 year, 2 and 3 years of age; General linear models were employed for the analyses adjusted for gender, passive smoking and number of older children

\begin{tabular}{|c|c|c|c|c|c|c|c|c|c|c|c|c|c|c|c|c|c|}
\hline & \multirow[b]{2}{*}{ Eczema } & \multicolumn{4}{|c|}{6 months } & \multicolumn{4}{|c|}{ Year 1} & \multicolumn{4}{|c|}{ Year 2} & \multicolumn{4}{|c|}{ Year 3} \\
\hline & & GM & Lower & Upper & $\mathrm{p}$ & GM & Lower & Upper & $\mathrm{p}$ & GM & Lower & Upper & $\mathrm{P}$ & GM & Lower & Upper & $\mathrm{P}$ \\
\hline \multicolumn{18}{|c|}{$\operatorname{sIg} \mathrm{A}$} \\
\hline \multirow{2}{*}{$6 \mathrm{w}$} & Yes & 0.583 & 0.489 & 0.694 & 0.68 & 0.598 & 0.493 & 0.725 & 0.94 & 0.569 & 0.466 & 0.695 & 0.53 & 0.535 & 0.437 & 0.653 & 0.13 \\
\hline & No & 0.607 & 0.510 & 0.722 & & 0.593 & 0.505 & 0.697 & & 0.608 & 0.520 & 0.713 & & 0.631 & 0.540 & 0.739 & \\
\hline \multirow{2}{*}{$6 \mathrm{~m}$} & Yes & 0.567 & 0.463 & 0.692 & 0.97 & 0.629 & 0.505 & 0.784 & 0.17 & 0.552 & 0.436 & 0.699 & 0.79 & 0.530 & 0.414 & 0.679 & 0.50 \\
\hline & No & 0.569 & 0.466 & 0.696 & & 0.533 & 0.442 & 0.642 & & 0.571 & 0.473 & 0.689 & & 0.580 & 0.479 & 0.701 & \\
\hline \multicolumn{18}{|c|}{ Lysozyme } \\
\hline \multirow{2}{*}{$6 \mathrm{w}$} & Yes & 0.067 & 0.054 & 0.082 & 0.77 & 0.068 & 0.054 & 0.085 & 0.67 & 0.064 & 0.050 & 0.082 & 0.89 & 0.069 & 0.054 & 0.088 & 0.35 \\
\hline & No & 0.065 & 0.053 & 0.079 & & 0.065 & 0.053 & 0.078 & & 0.063 & 0.052 & 0.077 & & 0.061 & 0.050 & 0.074 & \\
\hline \multirow{2}{*}{$6 \mathrm{~m}$} & Yes & 0.102 & 0.082 & 0.126 & 0.91 & 0.110 & 0.087 & 0.139 & 0.32 & 0.100 & 0.078 & 0.128 & 1.0 & 0.121 & 0.092 & 0.158 & 0.056 \\
\hline & No & 0.100 & 0.081 & 0.124 & & 0.097 & 0.079 & 0.118 & & 0.100 & 0.081 & 0.123 & & 0.092 & 0.075 & 0.112 & \\
\hline \multicolumn{18}{|c|}{ Lactoferrin } \\
\hline \multirow{2}{*}{$6 \mathrm{w}$} & Yes & 2.795 & 2.300 & 3.395 & 0.008 & 2.517 & 2.020 & 3.135 & 0.53 & 2.672 & 2.116 & 3.378 & 0.18 & 2.866 & 2.240 & 3.670 & 0.054 \\
\hline & No & 2.059 & 1.692 & 2.504 & & 2.333 & 1.934 & 2.816 & & 2.257 & 1.866 & 2.729 & & 2.212 & 1.831 & 2.672 & \\
\hline \multirow{2}{*}{$6 \mathrm{~m}$} & Yes & 1.914 & 1.594 & 2.295 & 0.26 & 2.130 & 1.744 & 2.600 & 0.016 & 2.012 & 1.635 & 2.476 & 0.10 & 2.221 & 1.780 & 2.772 & 0.008 \\
\hline & No & 1.699 & 1.416 & 2.038 & & 1.640 & 1.390 & 1.936 & & 1.677 & 1.414 & 1.987 & & 1.619 & 1.371 & 1.911 & \\
\hline \multicolumn{18}{|c|}{ Total Protein } \\
\hline \multirow{2}{*}{$6 \mathrm{w}$} & yes & 12.45 & 10.68 & 14.50 & 0.69 & 12.65 & 10.70 & 14.98 & 0.54 & 12.21 & 10.19 & 14.63 & 0.94 & 11.85 & 9.83 & 14.27 & 0.58 \\
\hline & No & 12.03 & 10.34 & 13.98 & & 11.99 & 10.41 & 13.80 & & 12.29 & 10.65 & 14.19 & & 12.53 & 10.82 & 14.49 & \\
\hline \multirow{2}{*}{$6 \mathrm{~m}$} & yes & 10.07 & 8.68 & 11.69 & 0.42 & 11.36 & 9.64 & 13.39 & 0.14 & 11.30 & 9.52 & 13.40 & 0.19 & 10.38 & 8.62 & 12.52 & 0.95 \\
\hline & No & 10.80 & 9.33 & 12.51 & & 9.95 & 8.69 & 11.40 & & 10.02 & 8.73 & 11.50 & & 10.45 & 9.10 & 12.01 & \\
\hline
\end{tabular}


Dear Dr Paolo Matricardi:

\section{Re: PAI14-O-0162.R1}

Thank you very much for further reviewing our manuscript. We are grateful for the constructive comments and suggestions of the reviewers, and have revised the paper accordingly. Attached please find the revised manuscript. Our responses to the comments raised and corresponding changes made are listed below. We believe that all the issues raised have been addressed satisfactorily, and trust that the paper is now acceptable for publication in PAI. Thank you once again for your kind consideration.

Yours sincerely,

Professor P G Holt Division of Cell Biology Telethon Kids Institute

PO Box 855

West Perth WA 6872 Australia 
Zhang, G. and Lai, C. and Hartmann, P. and Oddy, W. and Kusel, M. and Sly, P. and Holt, P. 2014. Anti-Infective Proteins in Breast Milk and Asthma-Associated Phenotypes During Early Childhood. Pediatric Allergy and Immunology. 25 (6): pp. 544-551.

Editor's comments:

In Addition, the Editorial Office ask you to reduce the number of tables from 6 to 4 by shifting the tables 5 and 6 (or others at your choice) in the electronic repository. The text is also exceeding the Limit, please consider to shift paragraphs (at your choice) in the electronic repository.

Response: Tables 5 and 6 have been shifted in the electronic repository. To reduce the text we have shifted several paragraphs in the electronic repository and deleted redundant words. Word Count; 3022

Reviewer: 1

1. Overall fine, most points were addressed adequately. However, some points are still not clear and should be implemented to make the message and potential limitations as transparent as possible for the reader.

Response: We have added sentences in the discussion section to clarify the limitations of the study (Lines 298-304/Pages 13, 14 in the clean version).

2. Comment 18. Further, no logic is provided for thinking that the relations with atopy, for example, might be different at 6 months vs. 2 or 5 years.

Revised (Lines 215-217).

Line 215-217: there is a word missing.

Response: The missing word "cyclical" was added. The rationale is already present in the text (line 176/page 8).

Reviewer: 2

1. Definition of asthma (and other) outcomes: was this current asthma,during the last 12 months, asthma ever (similar for other outcomes): please specify. Were lung function data at later ages included in confirmation of the diagnosis? What about coexistence of diagnoses?

Response: In the cohort lung function was only measured in 10 years follow up and we have provided the definition of the outcome variables such as wheezing, asthma, atopy and eczema.

The definition of asthma and other outcomes is now included in the Legend of Table 2, correct? However, it would make it helpful for the reader to specifically explain it in a) either methods or b) results. Here, it needs to included that wheeze was defined by parental opinion (which is well known to be subjective and often not corresponding well with a doctor diagnosis) AND doctor diagnosis of asthma beyond the second birthday.

And what about coexistence of diagnoses ? This was not elucidated further.

Response: We have added the following sentences (in red) in the methodology section (Lines 129-132/Page 6):

"Eczema was defined as doctor diagnosis of eczema or atopic dermatitis experienced by child in last 12 months. Wheezing is the parental opinion of whether child wheezed in last 12 months. Asthma was defined as wheeze during last 12 months plus Doctor diagnosis of asthma beyond the second birthday." 
There was coexistence of diagnoses such as eczema and wheezing. Due to sample size we did not investigate the associations of coexistence of allergic symptoms with anti-infective proteins in breast milk.

4. Did you also perform longitudinal analyses on other outcomes than atopy and eczema? Please provide data on wheezing and/or asthma. Was an analysis performed on children which presented with consistent diagnoses over all ages? This may actually be the strongest outcome as compared to effects on different time frames, certainly giving additive information. How do the authors explain changes in prevalence at the different ages? This is particularly different for atopy. This also relates to the specific definition of the diagnoses (see point 1).

Response: Data from the published cohort studies indicate that the expression of both wheezing and atopic phenotypes fluctuates over time in children during the preschool years. We have provided the results for wheezing and asthma (Lines 255-262). We did not find significant associations between wheezing/asthma and milk protein levels in the cohort. For the relatively small sample size of the sub-group of the cohort we do not have power to further investigate the effects of milk proteins on transient/early or persistent/late onset wheezing. We also acknowledge that multiple tests may give some false positive associations.

This part should be discussed and included as limitation in the discussion.

Response: We have added following sentences in the discussion section (Lines 198302/Pages 13,14):

"Firstly regarding the lack of association between wheezing/asthma and levels of milk proteins we acknowledge the possible type II errors due to relatively small sample size, which also precluded further sub-group analysis on the effects of milk proteins on other outcomes. However, this is a longitudinal cohort with wheezing phenotypes comprehensively investigated, which is superior to a cross-sectional study."

6. The clearest and consistent findings seem to be the change in protein concentration. For the other graphs (e.g. Fig. 1) findings do not seem to be that consistent. Did you try adjusting your data for total protein concentration?

Response: Due to the high correlation and colinearity between individual protein and total protein concentration adjusting for total protein concentration is questionable. With the dataset we cannot further clarify the effects of individual proteins.

Also, this last part should be included as limitation in the discussion to be transparent.

Response: We have added the following sentence in the discussion section (Lines 302304/Page 14):

"There were strong correlations between levels of individual proteins and the total milk proteins. We, therefore, could not further clarify the effects of individual proteins in this cohort." 
Zhang, G. and Lai, C. and Hartmann, P. and Oddy, W. and Kusel, M. and Sly, P. and Holt, P. 2014. Anti-Infective Proteins in Breast Milk and Asthma-Associated Phenotypes During Early Childhood. Pediatric Allergy and Immunology. 25 (6): pp. 544-551.

a

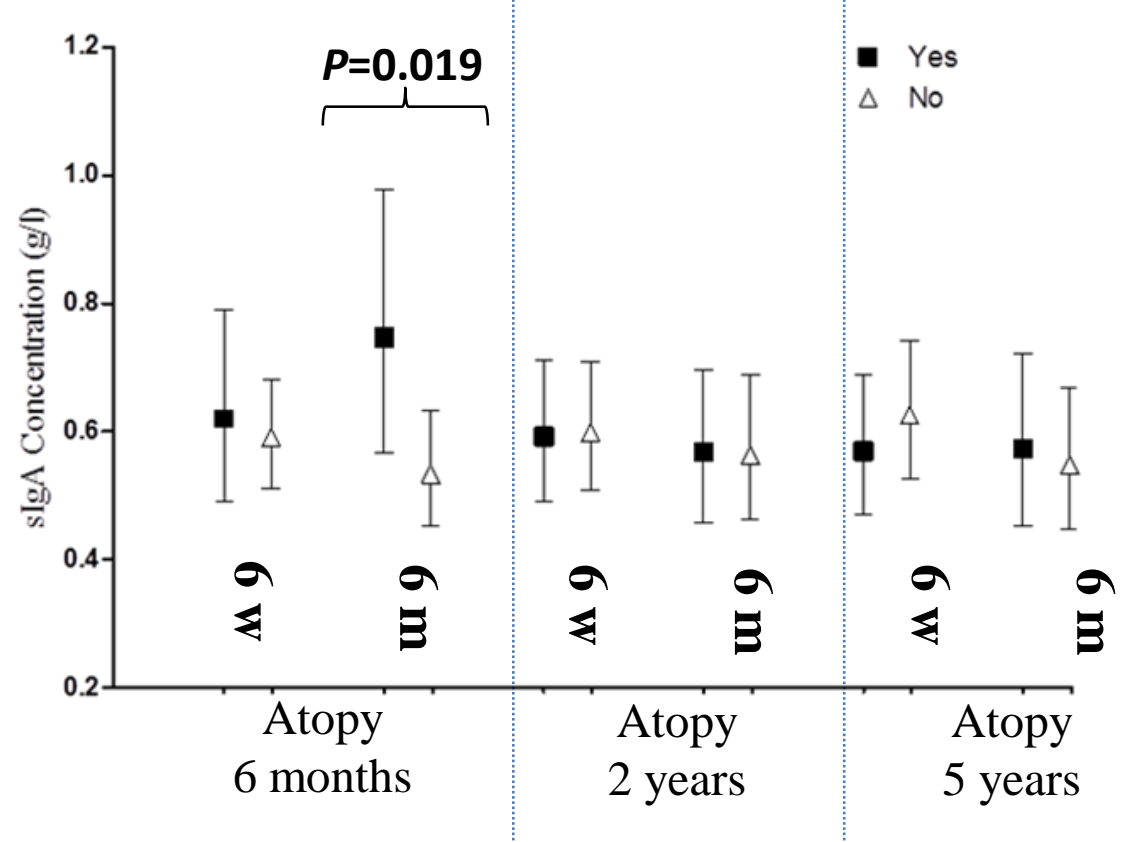

C

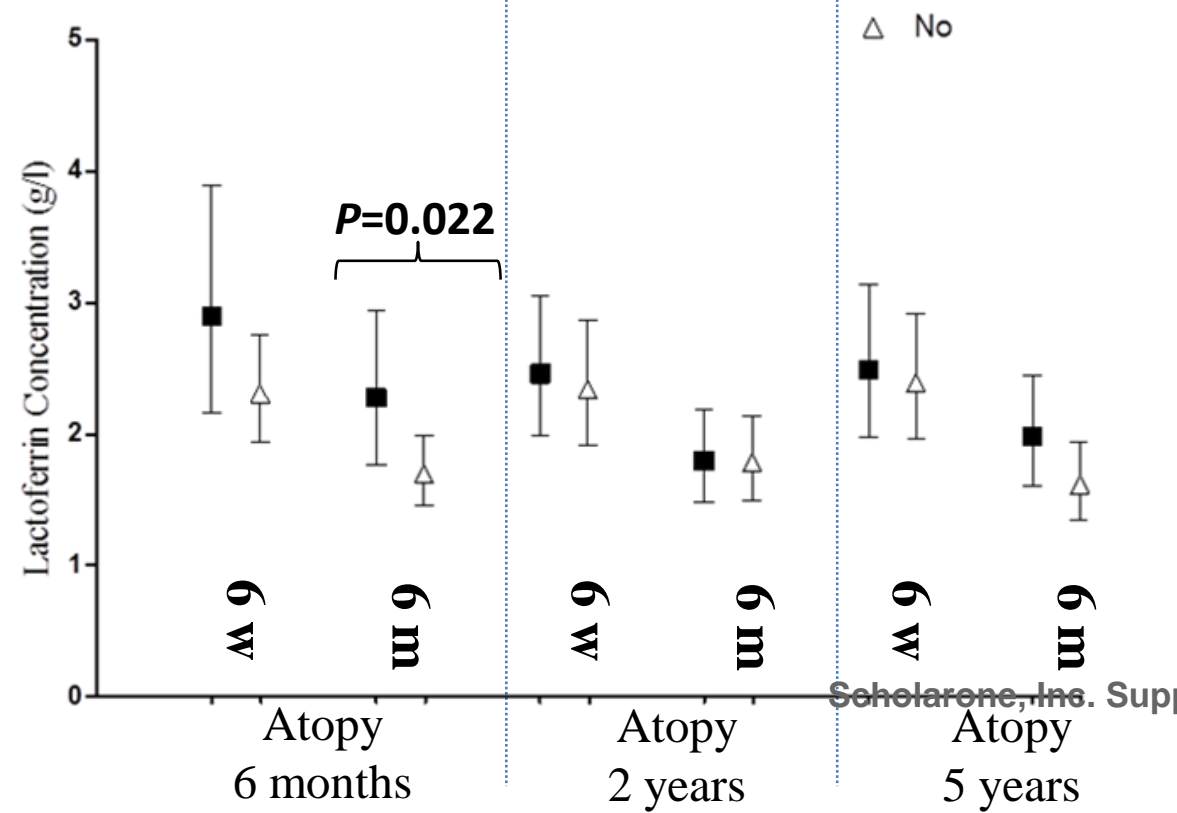

b
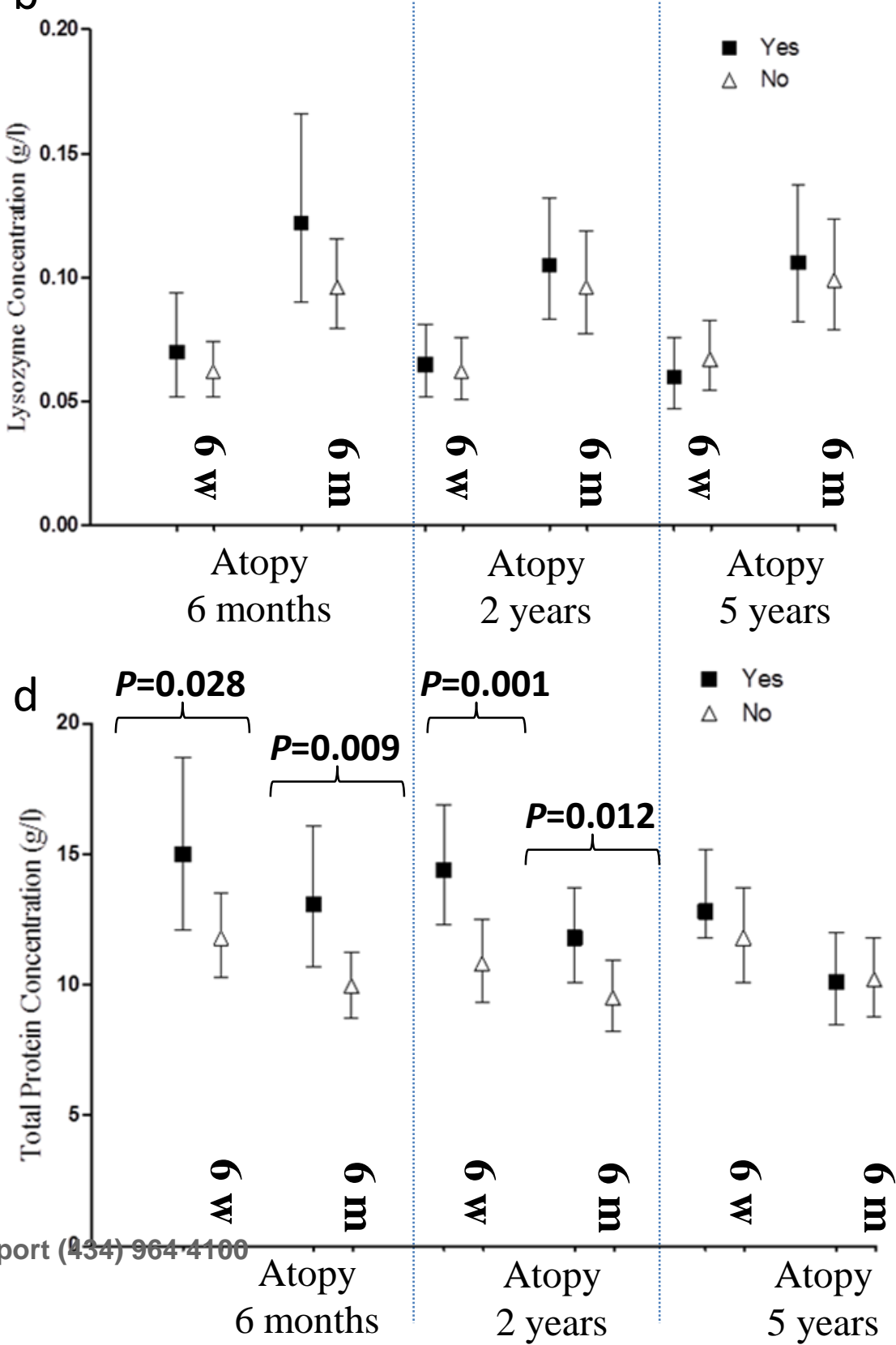


\section{Anti-infective proteins in breast milk and asthma-associated phenotypes during early childhood}

Zhang, Guicheng*1; Lai, Ching Tat* ${ }^{2}$; Hartmann, Peter $^{2}$; Oddy, Wendy $\mathrm{H}^{3}$; Kusel, Merci $\mathrm{MH}^{3}$; Sly, Peter D ${ }^{4}$; Holt Patrick $\mathrm{G}^{3,4}$

* contribute equally

${ }^{1}$ School of Public Health, Curtin University, Perth, Western Australia, Australia

${ }^{2}$ School of Chemistry and Biochemistry, Faculty of Science, The University of Western Australia, Perth, Western Australia, Australia

${ }^{3}$ Telethon Kids Institute, The University of Western Australia, Perth, Western Australia, Australia

${ }^{4}$ University of Queensland, Queensland Children's Medical Research Institute, Brisbane, Queensland, Australia

Running title: Breast milk proteins and risk for atopy/asthma

Corresponding Author

Prof Patrick G Holt

Professor P G Holt

Division of Cell Biology

Telethon Kids Institute

PO Box 855

West Perth WA 6872 Australia

Tel: $\quad+61894897838$

Email: Patrick.Holt@telethonkids.org.au

Marina.Stubbs@telethonkids.org.au

Dr Guicheng Zhang, School of Public Health, Curtin University

Email: brad.zhang@curtin.edu.au 
Zhang, G. and Lai, C. and Hartmann, P. and Oddy, W. and Kusel, M. and Sly, P. and Holt, P. 2014. Anti-Infective Proteins in Breast Milk and Asthma-Associated Phenotypes During Early Childhood. Pediatric Allergy and Immunology. 25 (6): pp. 544-551.

\section{Classification of LRI episodes}

Any episode with runny/blocked nose or dry cough was classified as a URI. Episodes that were associated with wheeze, or cough and rattly chest were considered to be LRI. Rattle/rattly chest was described as moist, wet noisy breath sounds from the child's chest. Wheeze was defined as a highpitched whistling sound heard coming from the chest, on expiration. LRI were further classified into wLRI and non-wheezy LRI based on the presence of any wheeze reported by the parent or family doctor.

\section{Lysozyme analysis}

Lysozyme in the samples was determined by a simple assay that was modified from Selsted \& Martinez ${ }^{18}$. The assay measured the loss of turbidity due to the lysis of Micrococcus lysodeikticus. The assay was modified that the reduction of the incubation time from 18 hours to 6 hours was found to still provide an effective of standard range for the assay.

\section{Lactoferrin and sIgA analysis}

Lactoferrin and $\operatorname{sgA}$ in the samples was determined by ELISA that was adapted from Tijssen ${ }^{19}$. In the sIgA ELISA, three antibodies were used: primary antibody (Rabbit anti-human - IgA IgG, 6000 fold in PBS, DAKO), secondary antibody (Mouse anti- human - IgA IgG, 5000 fold in PBS/Tween containing 1g/l BSA, DAKO) and third antibody (Goat anti- mouse - IgG IgG conjugated to horseradish peroxidase, 4000 fold in PBS/Tween containing 1g/l BSA, Bio-Rad). Standard IgA from human colostrum was prepared in PBS/Tween (range from 0 to $0.4 \mathrm{mg} / \mathrm{ml}$, Sigma). Milk samples were diluted 5000 fold in PBS/Tween for analysis. 
In the lactoferrin ELISA, two antibodies were used: primary antibody (anti- human lactoferrin, 4000 fold in PBS, ICN) and second antibody (anti- human lactoferrin conjugated to HRP was diluted 5,000 fold in PBS/Tween containing 1g/l BSA, ICN). Human lactoferrin standard was prepared in PBS/Tween (range from 0 to $0.02 \mathrm{mg} / \mathrm{ml}$, ICN). Milk samples were diluted 200,000 fold in PBS Tween.

\section{Total protein}

Total protein in the samples was determined by a protein assay that measured the binding of the protein dye (Bio-Rad) to the primarily basic and aromatic amino acid residues of the proteins. The dye was diluted 1:4 v/v and filtered with Whatman \#1 filter paper prior to use. To overcome the problems inherent in the choice of a milk standard, the protein concentration of an aliquot of mature breast milk

was determined by the Kjeldahl procedure ${ }^{20,21}$. The remaining sample was then diluted with double deionised water to provide a range of standards ( 0 to $1 \mathrm{~g} / \mathrm{l})$. The defatted milk samples were diluted 30 fold for the assay. Standards and diluted samples $(5 \mu \mathrm{l})$ were pipetted into a microtitre plate (96 wells plate, ICN). The diluted dye reagent $(250 \mu \mathrm{l})$ was added and mixed with the plate mixer (WellMix2, Australia). The absorbance of each sample/standard was measure at $620 \mathrm{~nm}$ with the Multiskan plate reader until the maximum absorbance was reached in approximately 20 minutes. 
Zhang, G. and Lai, C. and Hartmann, P. and Oddy, W. and Kusel, M. and Sly, P. and Holt, P. 2014. Anti-Infective Proteins in Breast Milk and Asthma-Associated Phenotypes During Early Childhood. Pediatric Allergy and Immunology. 25 (6): pp. 544-551.

Supplementary Table 1 Incidence rate ratios (IRR) of breast milk proteins for upper respiratory infection in the first three years of life; Poisson regression models were employed for the analyses adjusted for gender, passive smoking and number of older children

\begin{tabular}{|c|c|c|c|c|c|}
\hline & & \multirow{2}{*}{ IRR } & \multirow{2}{*}{$\mathrm{p}$} & \multicolumn{2}{|c|}{$95 \% \mathrm{CI}$} \\
\hline & & & & Lower & Upper \\
\hline \multicolumn{6}{|l|}{ Year 1} \\
\hline \multirow{2}{*}{ Log value of sIgA } & $6 \mathrm{~W}$ & 0.830 & 0.035 & 0.698 & 0.987 \\
\hline & $6 \mathrm{M}$ & 0.881 & 0.079 & 0.765 & 1.015 \\
\hline \multirow{2}{*}{ Log value of Lysozyme } & $6 \mathrm{~W}$ & 0.993 & 0.93 & 0.861 & 1.147 \\
\hline & $6 \mathrm{M}$ & 0.952 & 0.482 & 0.829 & 1.093 \\
\hline \multirow{2}{*}{$\begin{array}{l}\text { Log value of } \\
\text { Lactoferrin }\end{array}$} & $6 \mathrm{~W}$ & 0.957 & 0.544 & 0.832 & 1.102 \\
\hline & $6 \mathrm{M}$ & 0.803 & 0.008 & 0.682 & 0.945 \\
\hline \multirow{2}{*}{$\begin{array}{c}\text { Log value of total } \\
\text { proteins }\end{array}$} & $6 \mathrm{~W}$ & 0.928 & 0.457 & 0.761 & 1.131 \\
\hline & $6 \mathrm{M}$ & 0.867 & 0.172 & 0.707 & 1.064 \\
\hline \multicolumn{6}{|l|}{ Year 2} \\
\hline \multirow{2}{*}{ Log value of $\operatorname{sIg} A$} & $6 \mathrm{~W}$ & 0.793 & 0.005 & 0.673 & 0.934 \\
\hline & $6 \mathrm{M}$ & 0.934 & 0.409 & 0.795 & 1.098 \\
\hline \multirow{2}{*}{ Log value of Lysozyme } & $6 \mathrm{~W}$ & 0.960 & 0.574 & 0.831 & 1.108 \\
\hline & $6 \mathrm{M}$ & 1.073 & 0.316 & 0.935 & 1.231 \\
\hline \multirow{2}{*}{$\begin{array}{c}\text { Log value of } \\
\text { Lactoferrin }\end{array}$} & $6 \mathrm{~W}$ & 0.886 & 0.083 & 0.772 & 1.016 \\
\hline & $6 \mathrm{M}$ & 0.814 & 0.015 & 0.691 & 0.960 \\
\hline \multirow{2}{*}{$\begin{array}{l}\text { Log value of total } \\
\text { proteins }\end{array}$} & $6 \mathrm{~W}$ & 0.860 & 0.139 & 0.705 & 1.050 \\
\hline & $6 \mathrm{M}$ & 0.892 & 0.267 & 0.730 & 1.091 \\
\hline \multicolumn{6}{|l|}{ Year 3} \\
\hline \multirow{2}{*}{ Log value of sIgA } & $6 \mathrm{~W}$ & 1.074 & 0.455 & 0.891 & 1.294 \\
\hline & $6 \mathrm{M}$ & 1.125 & 0.150 & 0.958 & 1.321 \\
\hline \multirow{2}{*}{ Log value of Lysozyme } & $6 \mathrm{~W}$ & 0.973 & 0.710 & 0.841 & 1.125 \\
\hline & $6 \mathrm{M}$ & 1.013 & 0.860 & 0.881 & 1.164 \\
\hline Log value of & $6 \mathrm{~W}$ & 0.991 & 0.909 & 0.851 & 1.155 \\
\hline Lactoferrin & $6 \mathrm{M}$ & 0.955 & 0.599 & 0.805 & 1.134 \\
\hline Log value of total & $6 \mathrm{~W}$ & 0.987 & 0.905 & 0.793 & 1.228 \\
\hline proteins & $6 \mathrm{M}$ & 0.869 & 0.211 & 0.698 & 1.082 \\
\hline
\end{tabular}


Supplementary Table 2 Incidence rate ratios (IRR) of breast milk proteins for wheezing lower respiratory infection in the first three years of life; Poisson regression models were employed for the analyses with gender, passive smoking and number of older children adjusted for

\begin{tabular}{|c|c|c|c|c|c|}
\hline & & \multirow{2}{*}{ IRR } & \multirow{2}{*}{$\mathrm{p}$} & \multicolumn{2}{|c|}{$95 \% \mathrm{CI}$} \\
\hline & & & & Lower & Upper \\
\hline \multicolumn{6}{|l|}{ Year 1} \\
\hline \multirow{2}{*}{ Log value of $\operatorname{sIg} A$} & $6 \mathrm{~W}$ & 0.777 & 0.283 & 0.491 & 1.231 \\
\hline & $6 \mathrm{M}$ & 1.364 & 0.170 & 0.876 & 2.126 \\
\hline \multirow{2}{*}{ Log value of Lysozyme } & $6 \mathrm{~W}$ & 1.437 & 0.047 & 1.004 & 2.055 \\
\hline & $6 \mathrm{M}$ & 1.783 & 0.001 & 1.277 & 2.488 \\
\hline \multirow{2}{*}{ Log value of Lactoferrin } & $6 \mathrm{~W}$ & 1.893 & 0.003 & 1.245 & 2.880 \\
\hline & $6 \mathrm{M}$ & 1.455 & 0.103 & 0.927 & 2.284 \\
\hline \multirow{2}{*}{$\begin{array}{c}\text { Log value of total } \\
\text { proteins }\end{array}$} & $6 \mathrm{~W}$ & 1.088 & 0.745 & 0.655 & 1.805 \\
\hline & $6 \mathrm{M}$ & 1.580 & 0.123 & 0.883 & 2.825 \\
\hline \multirow{3}{*}{$\begin{array}{c}\text { Year } 2 \\
\text { Log value of } \operatorname{sIg} \mathrm{A}\end{array}$} & & & & & \\
\hline & $6 \mathrm{~W}$ & 0.978 & 0.904 & 0.674 & 1.417 \\
\hline & $6 \mathrm{M}$ & 0.974 & 0.894 & 0.662 & 1.433 \\
\hline \multirow{2}{*}{ Log value of Lysozyme } & $6 \mathrm{~W}$ & 1.160 & 0.354 & 0.847 & 1.589 \\
\hline & $6 \mathrm{M}$ & 1.236 & 0.181 & 0.906 & 1.687 \\
\hline \multirow{2}{*}{ Log value of Lactoferrin } & $6 \mathrm{~W}$ & 1.210 & 0.261 & 0.868 & 1.686 \\
\hline & $6 \mathrm{M}$ & 0.984 & 0.931 & 0.676 & 1.432 \\
\hline \multirow{2}{*}{$\begin{array}{c}\text { Log value of total } \\
\text { proteins }\end{array}$} & $6 \mathrm{~W}$ & 0.827 & 0.412 & 0.526 & 1.301 \\
\hline & $6 \mathrm{M}$ & 0.960 & 0.865 & 0.601 & 1.534 \\
\hline \multicolumn{6}{|l|}{ Year 3} \\
\hline \multirow{2}{*}{$\log$ value of $\operatorname{sIg} \mathrm{A}$} & $6 \mathrm{~W}$ & 0.923 & 0.706 & 0.608 & 1.401 \\
\hline & $6 \mathrm{M}$ & 0.672 & 0.011 & 0.496 & 0.912 \\
\hline \multirow{2}{*}{ Log value of Lysozyme } & $6 \mathrm{~W}$ & 0.778 & 0.146 & 0.555 & 1.091 \\
\hline & $6 \mathrm{M}$ & 1.124 & 0.485 & 0.810 & 1.560 \\
\hline \multirow{2}{*}{ Log value of Lactoferrin } & $6 \mathrm{~W}$ & 0.778 & 0.156 & 0.551 & 1.100 \\
\hline & $6 \mathrm{M}$ & 1.072 & 0.736 & 0.714 & 1.610 \\
\hline \multirow{2}{*}{$\begin{array}{l}\text { Log value of total } \\
\text { proteins }\end{array}$} & $6 \mathrm{~W}$ & 1.039 & 0.879 & 0.633 & 1.706 \\
\hline & $6 \mathrm{M}$ & 1.163 & 0.575 & 0.685 & 1.976 \\
\hline
\end{tabular}

